DOE/ID-22239

Prepared in cooperation with the U.S. Department of Energy

\title{
Completion Summary for Boreholes TAN-2271 and TAN-2272 at Test Area North, Idaho National Laboratory, Idaho
}

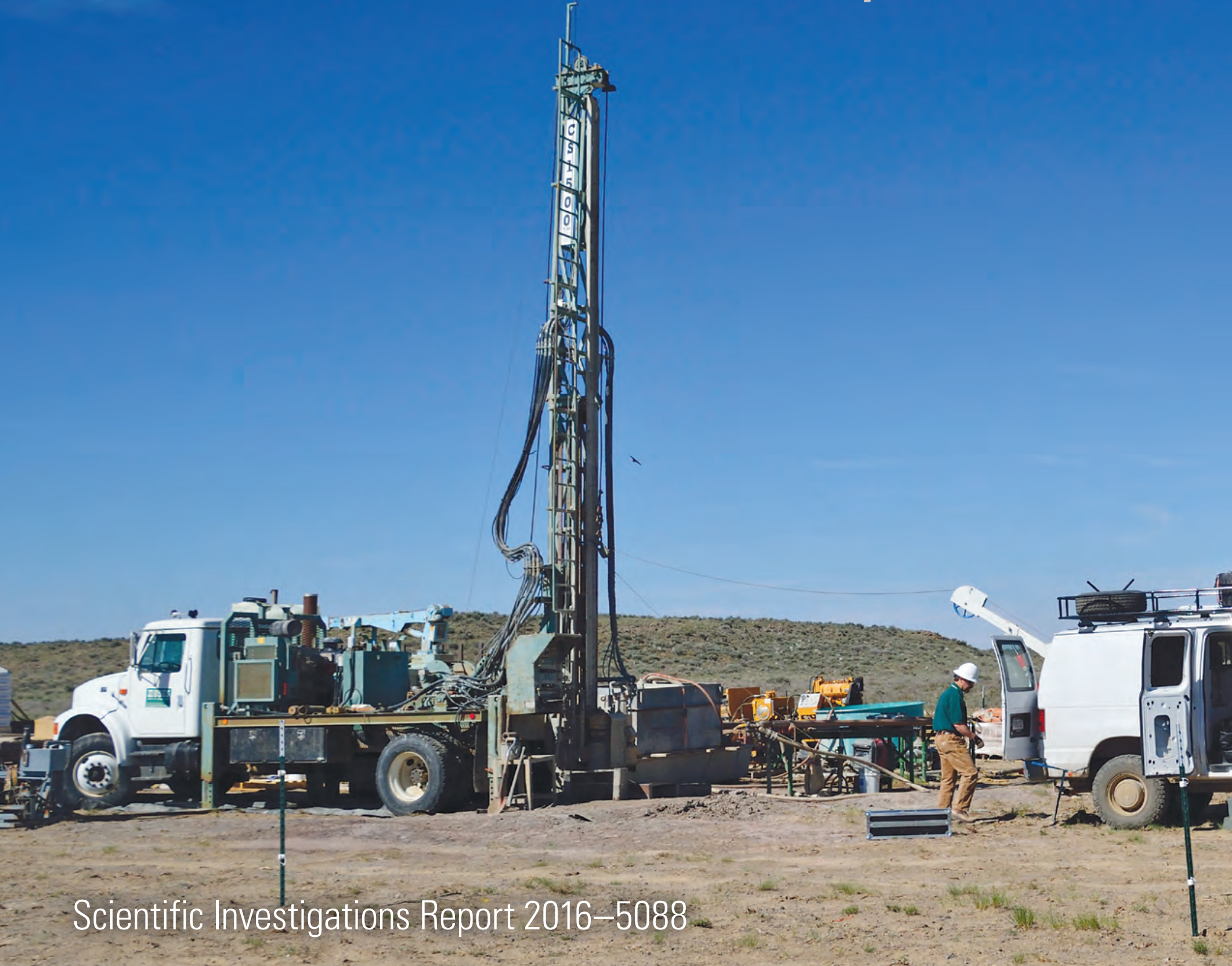

\section{U.S. Department of the Interior U.S. Geological Survey}


Cover: Photograph of U.S. Geological Survey Hydrologist collecting geophysical data from a newly drilled hole at well site USGS 142, Idaho National Laboratory, Idaho. Photograph by Charlie Jones, U.S. Geological Survey, April 28, 2015. 


\section{Completion Summary for Boreholes TAN-2271 and TAN-2272 at Test Area North, Idaho National Laboratory, Idaho}

By Brian V. Twining, Roy C. Bartholomay, and Mary K.V. Hodges

DOE/ID-22239

Prepared in cooperation with the U.S. Department of Energy

Scientific Investigations Report 2016-5088 


\title{
U.S. Department of the Interior SALLY JEWELL, Secretary
}

\section{U.S. Geological Survey Suzette M. Kimball, Director}

\author{
U.S. Geological Survey, Reston, Virginia: 2016
}

For more information on the USGS - the Federal source for science about the Earth, its natural and living resources, natural hazards, and the environment—visit http://www.usgs.gov or call 1-888-ASK-USGS.

For an overview of USGS information products, including maps, imagery, and publications, visit http://store.usgs.gov.

Any use of trade, firm, or product names is for descriptive purposes only and does not imply endorsement by the U.S. Government.

Although this information product, for the most part, is in the public domain, it also may contain copyrighted materials as noted in the text. Permission to reproduce copyrighted items must be secured from the copyright owner.

Suggested citation:

Twining, B.V., Bartholomay, R.C., and Hodges, M.K.V., 2016, Completion summary for boreholes TAN-2271 and TAN-2272 at Test Area North, Idaho National Laboratory, Idaho: U.S. Geological Survey Scientific Investigations Report 2016-5088 (DOE/ID-22239), 37 p., plus appendixes, http://dx.doi.org/10.3133/sir20165088.

ISSN 2328-0328 (online) 


\section{Contents}

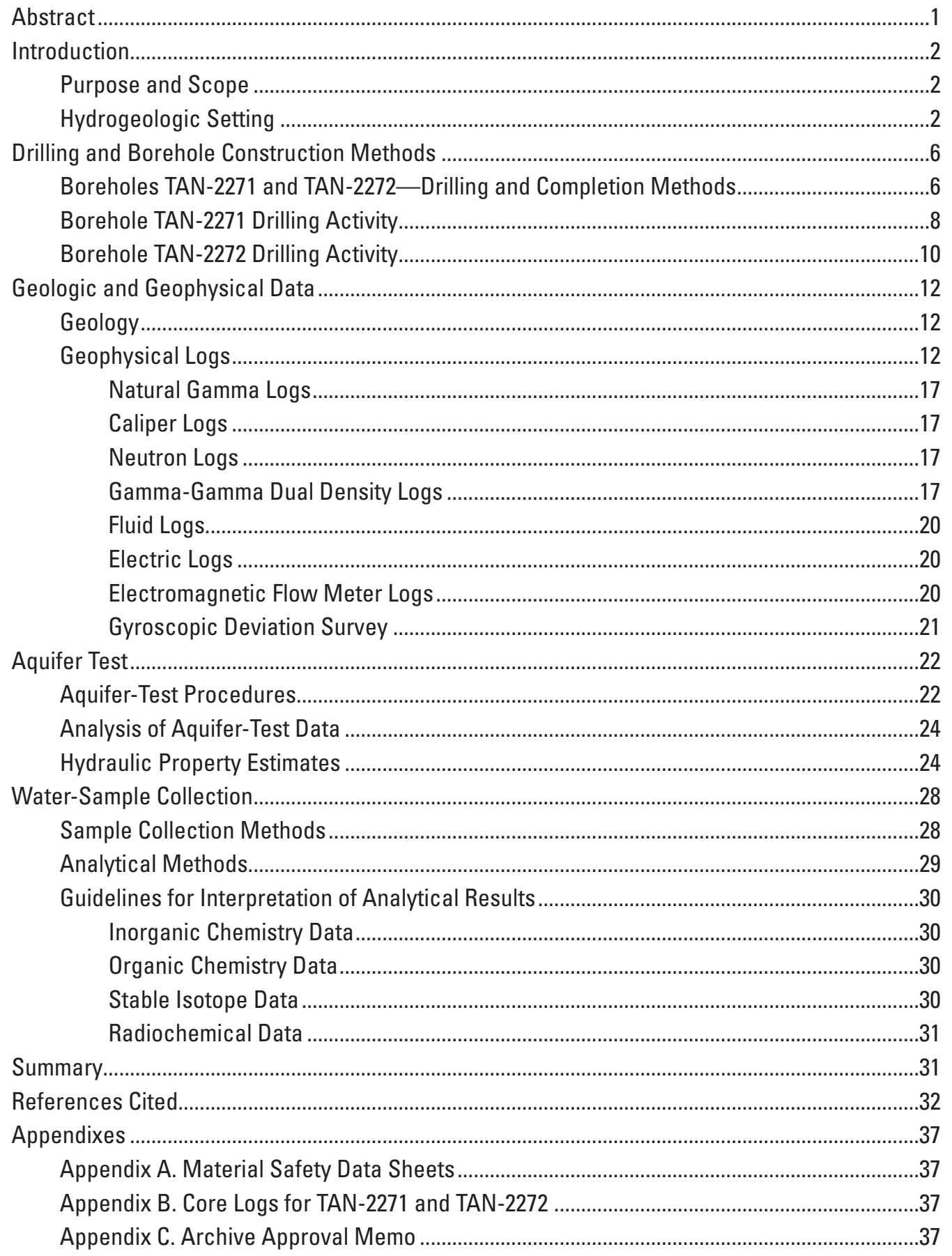




\section{Figures}

1. Map showing location of selected facilities at Idaho National Laboratory, Idaho

2. Map showing location of boreholes TAN-2271 and TAN-2272 and selected monitor wells, Test Area North, Idaho National Laboratory, Idaho

3. Diagram and graphs showing idealized typical olivine tholeiite pahoehoe basalt flow.

4. Diagram and photographs showing PQ-size coring system similar to one used for coring ......

5. Diagram showing final constructed borehole TAN-2271, Test Area North, Idaho National Laboratory, Idaho.

6. Diagram showing final constructed borehole TAN-2272, Test Area North, Idaho National Laboratory, Idaho.

7. Geophysical and lithologic logs run from total depth to land surface and lithologic logs described from cores, video logs, and geophysical logs for borehole TAN-2271, Test Area North, Idaho National Laboratory, Idaho.

8. Geophysical and lithologic logs run from total depth to land surface and lithologic logs described from cores, video logs, and geophysical logs for borehole TAN-2272, Test Area North, Idaho National Laboratory, Idaho.

9. Diagram showing drilling and construction stages in which geophysical logging was done for boreholes TAN-2271 and TAN-2272, Test Area North, Idaho National Laboratory, Idaho

10. Expanded geophysical and lithologic logs with focus on depths $225-282$ feet below land surface for borehole TAN-2271, Test Area North, Idaho National Laboratory, Idaho

11. Expanded geophysical and lithologic logs with focus on depths 225-282 feet below land surface for borehole TAN-2272, Test Area North, Idaho National Laboratory, Idaho

12. Diagrams showing gyroscopic deviation data collected for boreholes TAN-2271 and TAN-2272, Test Area North, Idaho National Laboratory, Idaho..

13. Diagram showing idealized placement of dataloggers during aquifer testing at wells TAN-2271 and TAN-2272, Test Area North, Idaho National Laboratory, Idaho ......23

14. Graph showing pumping rates during the aquifer tests at wells TAN-2271 and TAN-2272, Test Area North, Idaho National Laboratory, Idaho.

15. Graphs showing aquifer test 1 and 2 pumping well time series for wells TAN-2271 and TAN-2272, Test Area North, Idaho National Laboratory, Idaho.

16. Graphs showing aquifer test 1 and 2 observation well time series for wells TAN-2271 and TAN-2272, Test Area North, Idaho National Laboratory, Idaho. 


\section{Tables}

1. Location and completion information for boreholes TAN-2271 and TAN-2272, Test

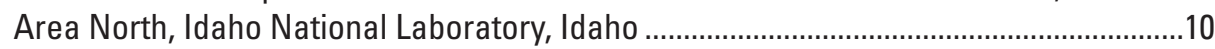

2. Geophysical and video log data collected at boreholes TAN-2271 and TAN-2272, Test Area North, Idaho National Laboratory, Idaho .....................................................13

3. Gyroscopic deviation data from processed survey for boreholes TAN-2271 and TAN-2272, Test Area North, Idaho National Laboratory, Idaho........................................22

4. Comparison of transmissivity values estimated from aquifer tests at wells near wells TAN-2271 and TAN-2272, near Test Area North, Idaho National Laboratory, Idaho

5. Concentrations of selected chemical and radiochemical constituents in water from wells TAN-2271 and TAN-2272, Test Area North, Idaho National Laboratory, Idaho ......28

\section{Conversion Factors}

Inch/Pound to International System of Units

\begin{tabular}{|c|c|c|}
\hline Multiply & By & To obtain \\
\hline \multicolumn{3}{|c|}{ Length } \\
\hline inch (in.) & 2.54 & centimeter $(\mathrm{cm})$ \\
\hline foot $(\mathrm{ft})$ & 0.3048 & meter (m) \\
\hline mile (mi) & 1.609 & kilometer (km) \\
\hline \multicolumn{3}{|c|}{ Volume } \\
\hline gallon (gal) & 3.785 & liter (L) \\
\hline cubic foot $\left(\mathrm{ft}^{3}\right)$ & 28.32 & cubic decimeter $\left(\mathrm{dm}^{3}\right)$ \\
\hline cubic foot $\left(\mathrm{ft}^{3}\right)$ & 0.02832 & cubic meter $\left(\mathrm{m}^{3}\right)$ \\
\hline liter (L) & 33.82 & ounce, fluid (fl. oz) \\
\hline \multicolumn{3}{|c|}{ Flow rate } \\
\hline foot per minute (ft/min) & 0.3048 & meter per minute (m/min) \\
\hline foot per day (ft/d) & 0.3048 & meter per day (m/d) \\
\hline gallon per minute (gal/min) & 0.06309 & liter per second (L/s) \\
\hline \multicolumn{3}{|c|}{ Pressure } \\
\hline atmosphere, standard (atm) & 101.3 & kilopascal (kPa) \\
\hline pound per square inch (lb/in²) & 6.895 & kilopascal (kPa) \\
\hline \multicolumn{3}{|c|}{ Radioactivity } \\
\hline picocurie per liter (pCi/L) & 0.037 & becquerel per liter $(\mathrm{Bq} / \mathrm{L})$ \\
\hline \multicolumn{3}{|c|}{ Specific capacity } \\
\hline $\begin{array}{l}\text { gallon per minute per foot } \\
[(\text { gal } / \mathrm{min}) / \mathrm{ft})]\end{array}$ & 0.2070 & liter per second per meter $[(\mathrm{L} / \mathrm{s}) / \mathrm{m}]$ \\
\hline \multicolumn{3}{|c|}{ Hydraulic conductivity } \\
\hline foot per day (ft/d) & 0.3048 & meter per day (m/d) \\
\hline \multicolumn{3}{|c|}{ Hydraulic gradient } \\
\hline foot per mile (ft/mi) & 0.1894 & meter per kilometer (m/km) \\
\hline \multicolumn{3}{|c|}{ Transmissivity* } \\
\hline foot squared per day $\left(\mathrm{ft}^{2} / \mathrm{d}\right)$ & 0.09290 & meter squared per day $\left(\mathrm{m}^{2} / \mathrm{d}\right)$ \\
\hline
\end{tabular}

Temperature in degrees Celsius $\left({ }^{\circ} \mathrm{C}\right)$ may be converted to degrees Fahrenheit $\left({ }^{\circ} \mathrm{F}\right)$ as follows:

$$
{ }^{\circ} \mathrm{F}=\left(1.8 x^{\circ} \mathrm{C}\right)+32 .
$$




\section{Datums}

Vertical coordinate information is referenced to the National Geodetic Vertical Datum of 1929 (NGVD 29).

Horizontal coordinate information is referenced to the North American Datum of 1927 (NAD 27). Altitude, as used in this report, refers to distance above the vertical datum.

\section{Supplemental Information}

*Transmissivity: The standard unit for transmissivity is cubic foot per day per square foot times foot of aquifer thickness $\left[\left(\mathrm{ft}^{3} / \mathrm{d}\right) / \mathrm{ft}^{2}\right] \mathrm{ft}$. In this report, the mathematically reduced form, foot squared per day $\left(\mathrm{ft}^{2} / \mathrm{d}\right)$, is used for convenience.

Specific conductance is given in microsiemens per centimeter at 25 degrees Celsius $\left(\mu \mathrm{S} / \mathrm{cm}\right.$ at $\left.25^{\circ} \mathrm{C}\right)$.

Concentrations of chemical constituents in water are given either in milligrams per liter (mg/L) or micrograms per liter ( $\mu \mathrm{g} / \mathrm{L})$.

\section{Abbreviations}

$\begin{array}{ll}\text { ATR Complex } & \begin{array}{l}\text { Advanced Test Reactor Complex (formerly RTC, Reactor Technology Complex } \\ \text { and TRA, Test Reactor Area) }\end{array} \\ \text { BLS } & \text { below land surface } \\ \text { CFA } & \text { Central Facilities Area } \\ \text { CPS } & \text { counts per second } \\ \text { DLDQC } & \text { detection limit by DQCALC } \\ \text { DOE } & \text { U.S. Department of Energy } \\ \text { DQCALC } & \text { detection and quantitation calculation } \\ \text { EMFM } & \text { electromagnetic flow meter } \\ \text { EPA } & \text { Environmental Protection Agency } \\ \text { ESRP } & \text { eastern Snake River Plain } \\ \text { INL } & \text { Idaho National Laboratory } \\ \text { INTEC } & \text { Idaho Nuclear Technology and Engineering Center } \\ \text { MCL } & \text { maximum contaminant level } \\ \text { MFC } & \text { Materials and Fuels Complex } \\ \text { MRL } & \text { minimum reporting level } \\ \text { N } & \text { nitrogen } \\ \text { NWOL } & \text { National Water Quality Laboratory (USGS) } \\ \text { P } & \text { phosphorus } \\ \text { PO } & \text { core rod sizing } \\ \text { RSIL } & \text { Reston Stable Isotope Laboratory } \\ \text { RESL } & \text { Radiological and Environmental Sciences Laboratory (DOE) } \\ \text { RWMC } & \text { Radioactive Waste Management Complex } \\ \text { S } & \text { sample standard deviation } \\ \text { SDS } & \text { Safety data sheet } \\ \text { SS } & \text { stainless steel } \\ \text { TAN } & \text { Test Area North } \\ \text { USGS } & \text { U.S. Geological Survey } \\ \text { VOC } & \text { volatile organic compound } \\ \text { WGS } & \text { Waste Generator Services }\end{array}$




\title{
Completion Summary for Boreholes TAN-2271 and TAN-2272 at Test Area North, Idaho National Laboratory, Idaho
}

\author{
By Brian V. Twining, Roy C. Bartholomay, and Mary K.V. Hodges
}

\section{Abstract}

In 2015, the U.S. Geological Survey, in cooperation with the U.S. Department of Energy, drilled and constructed boreholes TAN-2271 and TAN-2272 for stratigraphic framework analyses and long-term groundwater monitoring of the eastern Snake River Plain aquifer at the Idaho National Laboratory in southeast Idaho. Borehole TAN-2271 initially was cored to collect continuous geologic data, and then re-drilled to complete construction as a monitor well. Borehole TAN-2272 was partially cored between 210 and 282 feet (ft) below land surface (BLS) then drilled and constructed as a monitor well. Boreholes TAN-2271 and TAN-2272 are separated by about $63 \mathrm{ft}$ and have similar geologic layers and hydrologic characteristics based on geologic, geophysical, and aquifer test data collected. The final construction for boreholes TAN-2271 and TAN-2272 required 10-inch (in.) diameter carbon-steel well casing and 9.9-in. diameter open-hole completion below the casing to total depths of 282 and $287 \mathrm{ft}$ BLS, respectively. Depth to water is measured near $228 \mathrm{ft} \mathrm{BLS}$ in both boreholes. Following construction and data collection, temporary submersible pumps and water-level access lines were placed to allow for aquifer testing, for collecting periodic water samples, and for measuring water levels.

Borehole TAN-2271 was cored continuously, starting at the first basalt contact (about $33 \mathrm{ft}$ BLS) to a depth of $284 \mathrm{ft}$ BLS. Excluding surface sediment, recovery of basalt and sediment core at borehole TAN-2271 was better than 98 percent. Based on visual inspection of core and geophysical data, material examined from 33 to $211 \mathrm{ft}$ BLS primarily consists of two massive basalt flows that are about 78 and $50 \mathrm{ft}$ in thickness and three sediment layers near 122, 197, and $201 \mathrm{ft} \mathrm{BLS}$. Between 211 and $284 \mathrm{ft}$ BLS, geophysical data and core material suggest a high occurrence of fractured and vesicular basalt. For the section of aquifer tested, there are two primary fractured aquifer intervals: the first between 235 and $255 \mathrm{ft}$ BLS and the second between 272 and $282 \mathrm{ft}$ BLS. Basalt texture for borehole TAN-2271 generally was described as aphanitic, phaneritic, and porphyritic. Sediment layers, starting near $122 \mathrm{ft}$ BLS, generally were composed of fine-grained sand and silt with a lesser amount of clay. Basalt flows generally ranged in thickness from 2 to $78 \mathrm{ft}$ and varied from highly fractured to dense with high to low vesiculation. Geophysical data and limited core material collected from TAN-2272 show similar lithologic sequences to those reported for TAN-2271.

Geophysical and borehole video logs were collected during certain stages of the drilling and construction process at boreholes TAN-2271 and TAN-2272. Geophysical logs were examined synergistically with available core material to confirm geologic and hydrologic similarities and suggest possible fractured network interconnection between boreholes TAN-2271 and TAN-2272. Natural gamma log measurements were used to assess the completeness of the vapor port lines behind 10-in. diameter well casing. Electromagnetic flow meter results were used to identify downward flow conditions that exist for boreholes TAN-2271 and TAN-2272. Furthermore, gyroscopic deviation measurements were used to measure horizontal and vertical displacement at all depths in boreholes TAN-2271 and TAN-2272.

After borehole construction was completed, single-well aquifer tests were done within wells TAN-2271 and TAN-2272 to provide estimates of transmissivity and hydraulic conductivity. The transmissivity and hydraulic conductivity were estimated for the pumping well and observation well during the aquifer tests conducted on August 25 and August 27, 2015. Estimates for transmissivity range from $4.1 \times 10^{3}$ feet squared per day $\left(\mathrm{ft}^{2} / \mathrm{d}\right)$ to $8.1 \times 10^{3} \mathrm{ft}^{2} / \mathrm{d}$; estimates for hydraulic conductivity range from 5.8 to 11.5 feet per day (ft/d). Both TAN-2271 and TAN-2272 show sustained pumping rates of about 30 gallons per minute (gal/min) with measured drawdown in the pumping well of $1.96 \mathrm{ft}$ and $1.14 \mathrm{ft}$, respectively. The transmissivity estimates for wells tested were within the range of values determined from previous aquifer tests in other wells near Test Area North.

Groundwater samples were collected from both wells and were analyzed for cations, anions, metals, nutrients, volatile organic compounds, stable isotopes, and radionuclides. Groundwater samples for most of the inorganic constituents showed similar water chemistry in both wells. Groundwater samples for strontium-90, trichloroethene, and vinyl chloride exceeded maximum contaminant levels for public drinking water supplies in one or both wells. 


\section{Introduction}

The U.S. Geological Survey (USGS), in cooperation with the U.S. Department of Energy (DOE), has collected borehole information at the Idaho National Laboratory (INL) since 1949 to provide baseline data concerning the migration and disposition of radioactive and chemical wastes in the eastern Snake River Plain (ESRP) aquifer. The USGS is refining numerical models for the movement of groundwater and contaminants in the ESRP aquifer. Additional hydrogeologic and borehole information at and near Test Area North (TAN) is needed to understand groundwater flow and complete cross-borehole testing for ongoing studies at TAN (fig. 1). Geologic data along with hydraulic properties (transmissivity and hydraulic conductivity) are needed to define groundwater movement as it relates to contaminant transport of waste plumes at TAN.

The week of May 18, 2015, the USGS mobilized equipment to TAN to begin drilling for boreholes TAN-2271 and TAN-2272 (fig. 2). Drilling and construction for boreholes TAN-2271 and TAN-2272 were similar; however, TAN-2271 was cored from the first basalt contact to a depth of $284 \mathrm{ft}$ below land surface (BLS) and TAN-2272 was cored from 210 to $282 \mathrm{ft} \mathrm{BLS}$. Boreholes TAN-2271 and TAN-2272 were constructed with 10 -in. diameter well casing to depths of about 211 and $210 \mathrm{ft}$ BLS, respectively; furthermore, dual vapor extraction lines were placed behind well casing and vented from 133 to $137 \mathrm{ft}$ and from 193 to $197 \mathrm{ft}$ BLS in both boreholes. Below the 10-in. diameter well casing, boreholes TAN-2271 and TAN-2272 were open-hole constructed (9.9-in. diameter) to $289 \mathrm{ft}$ BLS. Drilling and construction took place between May 20 and August 11, 2015.

Various data were collected throughout the drilling process and compiled within this report. Geophysical data and downhole video were collected and examined to confirm placement of annular seal, vapor lines, open borehole conditions, and confirm areas of fractured and dense basalt. After construction, aquifer testing was done for wells TAN-2271 and TAN-2272 on August 25 and 27, 2015, respectively. Additionally, an extensive suite of groundwater samples was collected after purging to examine water chemistry at both well locations.

\section{Purpose and Scope}

The purpose of this study is to better understand the hydrogeology in the northern part of the INL, specifically at TAN. Geologic, geophysical, and aquifer test data were collected and analyzed to a depth of about $289 \mathrm{ft}$ BLS to determine lithologic and hydraulic properties along with fracture connection between a well pair located in close proximity for future remediation work. Additionally, water samples were collected and analyzed to provide water-quality data after construction. This report presents results of the drilling, coring, construction, geophysical logging, aquifer testing, and water sampling for boreholes TAN-2271 and TAN-2272. General lithologic descriptions of the drill core for borehole TAN-2271 and selected core from TAN-2272 are provided and detailed descriptions are included in the appendixes. This report presents a comprehensive suite of water samples collected for each well, and includes analyses of inorganic, organic, stable isotopes, and radionuclide constituents, and results.

\section{Hydrogeologic Setting}

The INL is in the west-central part of the ESRP (fig. 1). The ESRP is a northeast-trending structural basin about 200 miles (mi) long and 50-70 mi wide. The ESRP developed when the North American tectonic plate started moving southwestward over a fixed upper-mantle-melting anomaly beginning about 17 million years ago (Pierce and Morgan, 1992). Thermal disruption resulted in a time transgressing series of silicic volcanic fields, characterized by positive geoid anomalies, rhyolitic resurgent caldera eruptions, emplacement of a mid-crustal mafic sill, and subsidence with later basaltic plains magmatism (Braile and others, 1982; Shervais and others, 2006). The subsiding ESRP basin was filled with interbedded terrestrial sediments and Pleistocene to late Pliocene basalt, 0.6-1.2 mi thick (Whitehead, 1992). The basaltic rocks and sedimentary deposits make up the ESRP aquifer.

The ESRP is composed mostly of olivine tholeiite basalt flows, which erupted as tube-fed, inflated, pahoehoe flows that make up more than 85 percent of the subsurface volume of the ESRP at the INL (Anderson and Liszewski, 1997). Figure 3 includes a diagram of a lobe of a tube-fed pahoehoe ESRP basalt flow, showing cooling fractures that develop perpendicular to the exterior surfaces, vesicle zones and sheets, pipe vesicles, interior mega vesicles, and a diktytaxitic to massive core. The distribution of basalt flows is controlled by topography, rate of effusion, and duration of eruption. Near-vent flows are thinner than distal flows, and accumulations of thin flows have a larger volume of high conductivity zones than the same volume of thick flows (Anderson and others, 1999).

The part of the Snake River Plain aquifer that underlies the ESRP is one of the most productive aquifers in the United States (U.S. Geological Survey, 1985, p. 193). Groundwater in the ESRP aquifer generally moves from northeast to southwest, eventually discharging to springs along the Snake River downstream of Twin Falls, Idaho-about $100 \mathrm{mi}$ southwest of the INL (Whitehead, 1992). Water moves through basalt fracture zones at the tops, bases, and sides of basalt flows. Infiltration of surface water, groundwater pumping, geologic conditions, and seasonal fluxes of recharge and discharge locally affect the movement of groundwater (Garabedian, 1986). Recharge to the ESRP aquifer is primarily from infiltration of applied irrigation water, streamflow, precipitation, and groundwater inflow from adjoining mountain drainage basins (Ackerman and others, 2006). 


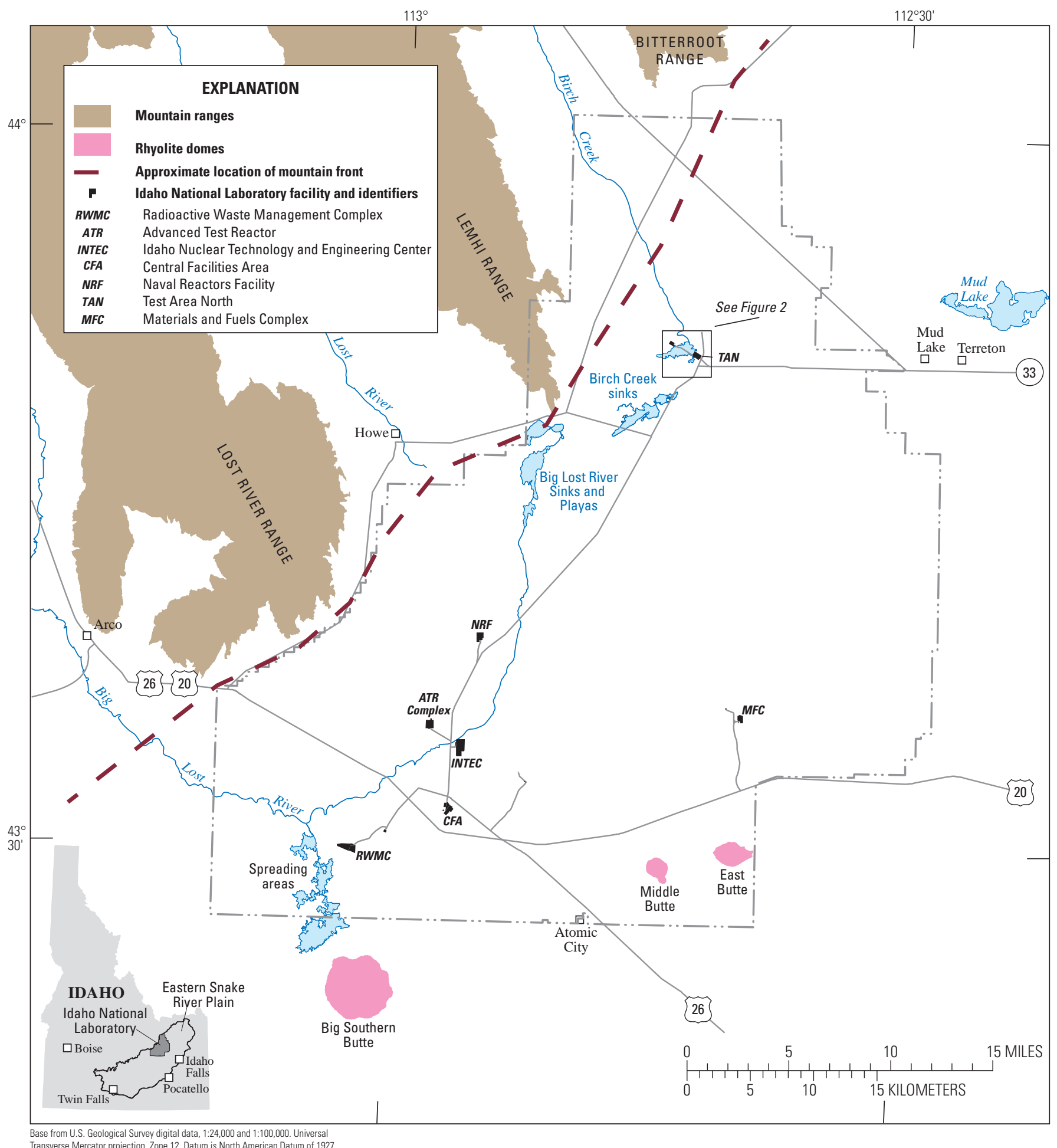

Figure 1. Location of selected facilities at Idaho National Laboratory, Idaho. 


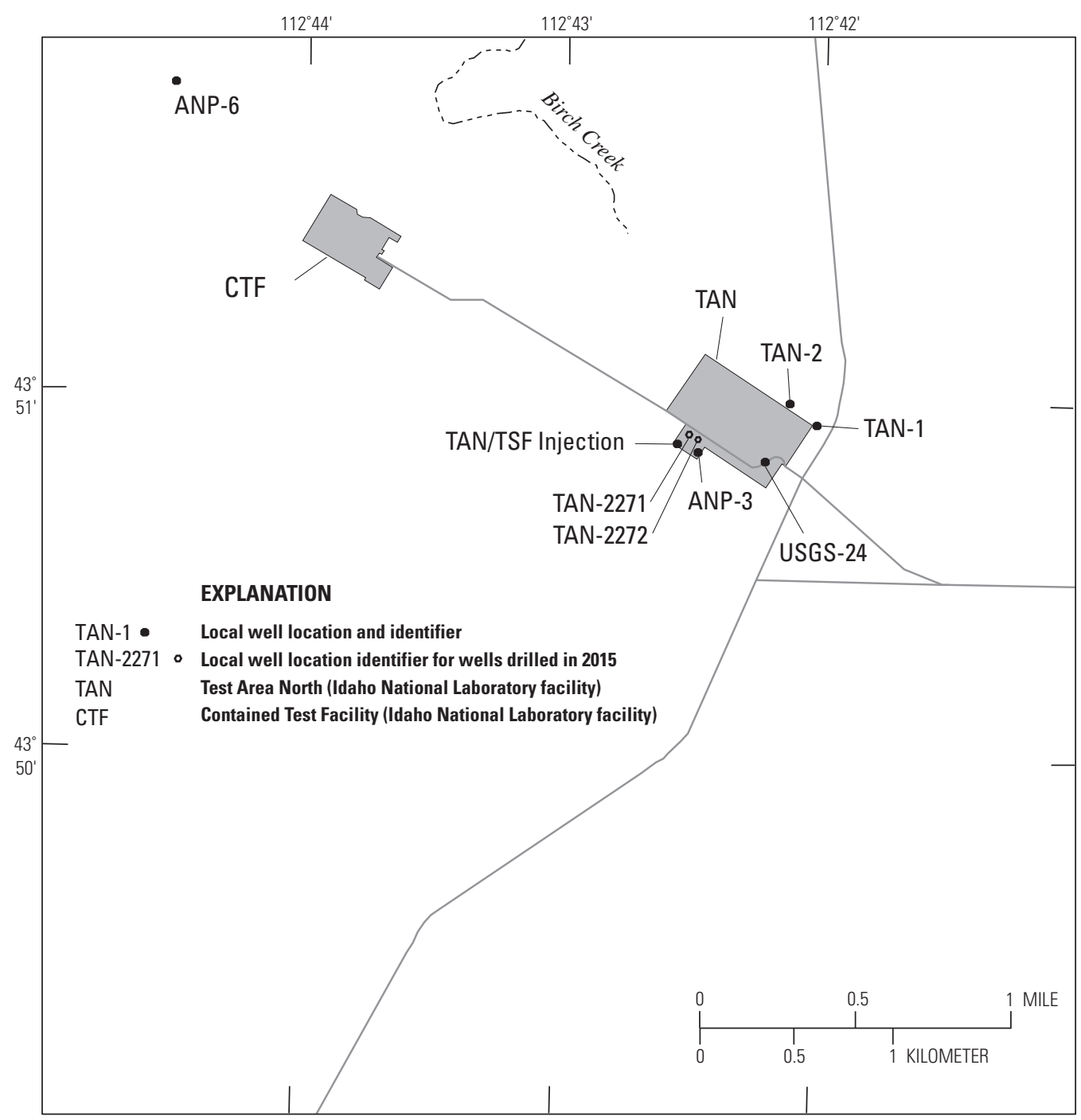

Figure 2. Location of boreholes TAN-2271 and TAN-2272 and selected monitor wells, Test Area North, Idaho National Laboratory, Idaho. 


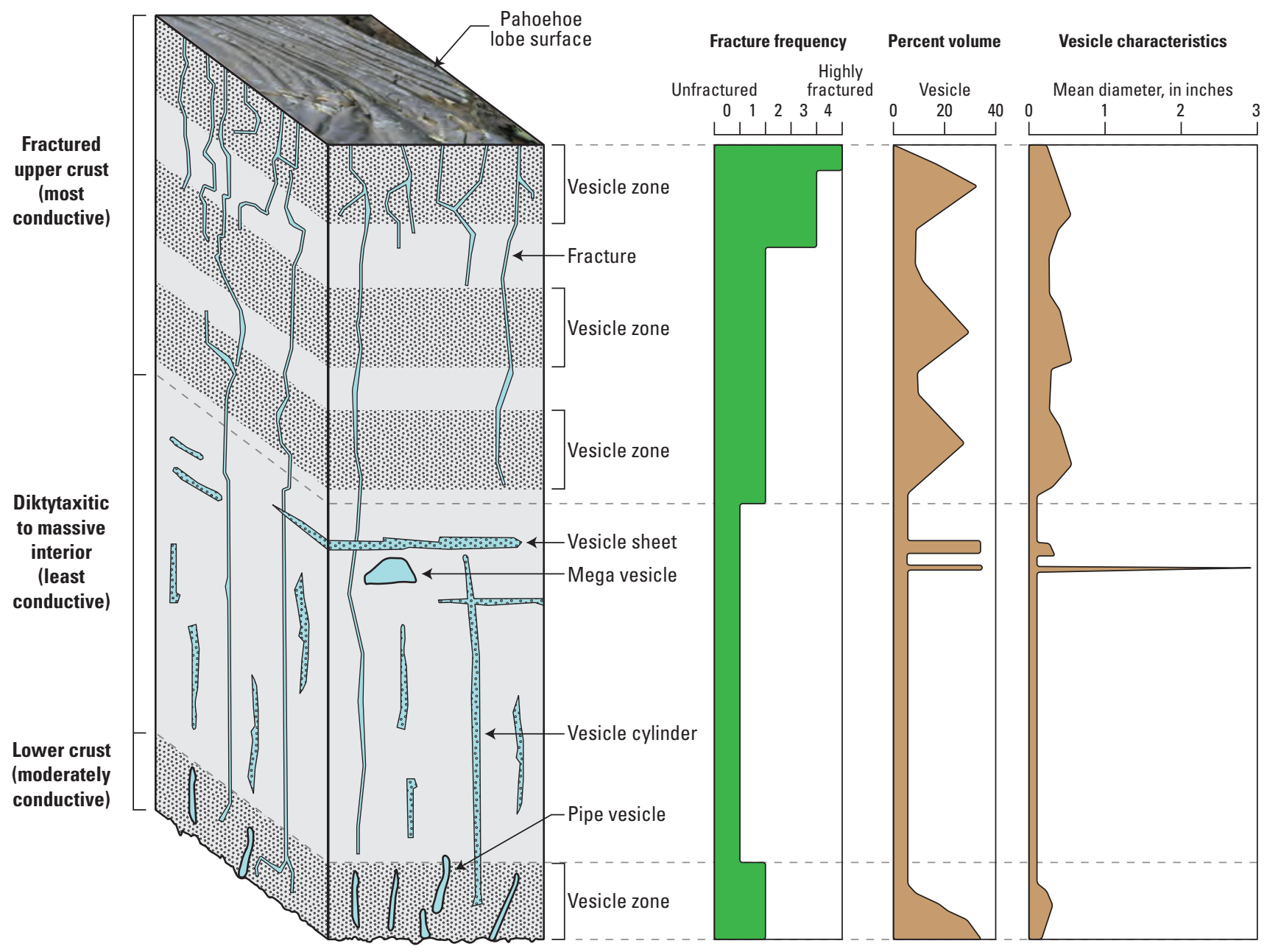

Figure 3. Idealized typical olivine tholeiite pahoehoe basalt flow (modified from Self and others, 1998, fig. 3, p. 90). The basalt flow is divided into three sections on the basis of vesicle characteristics and fracture frequency. Hydraulic conductivity is highest for the fractured upper crust, moderate for the lower crust, and lowest for the diktytaxitic to massive interior. The photograph of the pahoehoe lobe surface is courtesy of Scott Hughes, Emeritus Professor, Idaho State University, Pocatello, Idaho. 
In the northern part of the INL, the March-May 2011 water-table elevation ranged from about 4,560 to $4,550 \mathrm{ft}$ (Davis and others, 2013, fig. 9); at boreholes TAN-2271 and TAN-2272, the altitude of the water table is about 4,553 ft. Depth to water ranges from about $200 \mathrm{ft}$ BLS in the northern part of the INL to more than $900 \mathrm{ft}$ BLS in the southeastern part; depth to water measured in boreholes TAN-2271 and TAN-2272 is about $228 \mathrm{ft}$ BLS. Most groundwater moves through the upper 200-800 ft of basaltic rocks (Mann, 1986, p. 21). The estimated transmissivity for the upper part of the ESRP aquifer is 1.1 to $760,000 \mathrm{ft}^{2} / \mathrm{d}$ reported by Ackerman (1991, p. 30) and Bartholomay and others (1997, table 3). The hydraulic gradient at the INL ranges from 2 to 10 feet per mile (ft/mi); the average is about $4 \mathrm{ft} / \mathrm{mi}$ (Davis and others, 2013, fig. 9). Horizontal flow velocities of 2-20 ft/d have been calculated on the basis of the movement of various chemical and radiochemical constituents in different areas of the ESRP aquifer at the INL (Robertson and others, 1974; Mann and Beasley, 1994; Cecil and others, 2000; Busenberg and others, 2001). These flow rates equate to a travel time of about 70-700 years for water beneath the INL to travel to springs that discharge at the terminus of the ESRP aquifer near Twin Falls, Idaho (fig. 1). Localized tracer tests at the INL have shown vertical and horizontal transport rates as high as 60 and $150 \mathrm{ft} / \mathrm{d}$, respectively (Nimmo and others, 2002; Duke and others, 2007).

\section{Drilling and Borehole Construction Methods}

Drilling, well construction, and hydraulic testing by the USGS took place between May 21, 2015, and August 11, 2015. All activities were in accordance with the USGS INL Site Safety Plan and the INL Environmental Checklist requirements; additionally, the USGS completed and documented regular safety inspections and safety briefings. Safety Data Sheets for chemicals used during drilling are included in appendix A.

Prior to drilling startup, construction barriers were established and a job-site walkdown and pre-job safety briefings were done May 18 and May 20, 2015. Regular equipment inspections and safety discussions were documented and weekly drilling updates were distributed during the project. Where drilling was done inside of the TAN facility, drill cuttings and fluid that returned to the surface were diverted to waste containers (when necessary) and handled by Waste Generator Services (WGS) at the INL for disposal. Cutting returns that could not be diverted were excavated and cleared after construction. Fluid used during coring, drilling, and well construction was supplied through a potable water hydrant located near the drill site.

\section{Boreholes TAN-2271 and TAN-2272-Drilling and Completion Methods}

Borehole TAN-2271 was continuously cored from about 33 to $284 \mathrm{ft}$, where borehole TAN-2272 was cored from about 210 to $282 \mathrm{ft} \mathrm{BLS}$. Core drilling was done using a Christense ${ }^{\mathrm{TM}}$ CS 1500 rotary drilling rig and PQ-size coring system, where PQ refers to core rod sizing (drill-bit size about 4.8-in. diameter). The core system was setup with carbide and diamond core bits, core catchers, and latch assembly for core retrieval (fig. 4). Core was retrieved in 5-ft sections using a four-part wireline latching mechanism (quadlatch) at the top of the core-barrel assembly. After removal from the borehole, core was marked for orientation and depth in the field before boxing. Cores from the first basalt contact down to $210 \mathrm{ft}$ BLS were photographed and archived at the INL Lithologic Core Storage Library (Davis and others, 1997), which is operated by the USGS at the Central Facilities Area (CFA) (fig. 1). Core material recovered from boreholes TAN-2271 and TAN-2272 below $210 \mathrm{ft}$ BLS was not taken to the Core Storage Library where elevated gamma radiation was surveyed in recovered cores; therefore, borehole core was photographed and described in the field and then disposed through WGS. Elevated gamma radiation was measured in cores at land surface and in natural gamma logs from 216 to $225 \mathrm{ft}$ BLS and from 215 to $223 \mathrm{ft}$ BLS in boreholes TAN-2271 and TAN2272, respectively. Elevated gamma radiation observed in basalt rock suggest radionuclides from the decommissioned injection well precipitated out when the regional aquifer water levels were above $215 \mathrm{ft}$ BLS at this location (Bartholomay and Twining, 2015). The core material was not considered a health or safety risk; however, radiological control technicians onsite determined the core should not be released to the Core Storage Library where it shows residual elevated gamma radiation.

Auger, tri-cone, and downhole hammer drilling and setting 16-in. and 10-in. diameter casing segments were performed using a GEFCO ${ }^{\mathrm{TM}}$ SD-300 drill rig in boreholes TAN-2271 and TAN-2272. The rig was initially used to auger and (or) tricone drill and drive 16-in. diameter casing to the first basalt contact in boreholes TAN-2271 and TAN-2272. Additionally, the SD-300 drill rig was used to drill 15-in. and 9.9-in. diameter borehole sections during the construction phase. Spiral stabilizers, sized to the drill bit diameter, were used to keep the borehole straight and plumb while drilling. Air and water were the primary circulation fluids used while drilling; however; to remove cuttings from the 15-in. and 9.9-in. diameter borehole sections, a foam (Baroid ${ }^{\circledR}$ Quik-Foam ${ }^{\circledR}$ ) was introduced to improve cutting returns to surface (appendix A).

Pressurized air and water were used to complete PQ-coring for borehole TAN-2271 from about 33 to $284 \mathrm{ft}$ BLS and from 210 to $282 \mathrm{ft}$ BLS in borehole TAN-2272. 


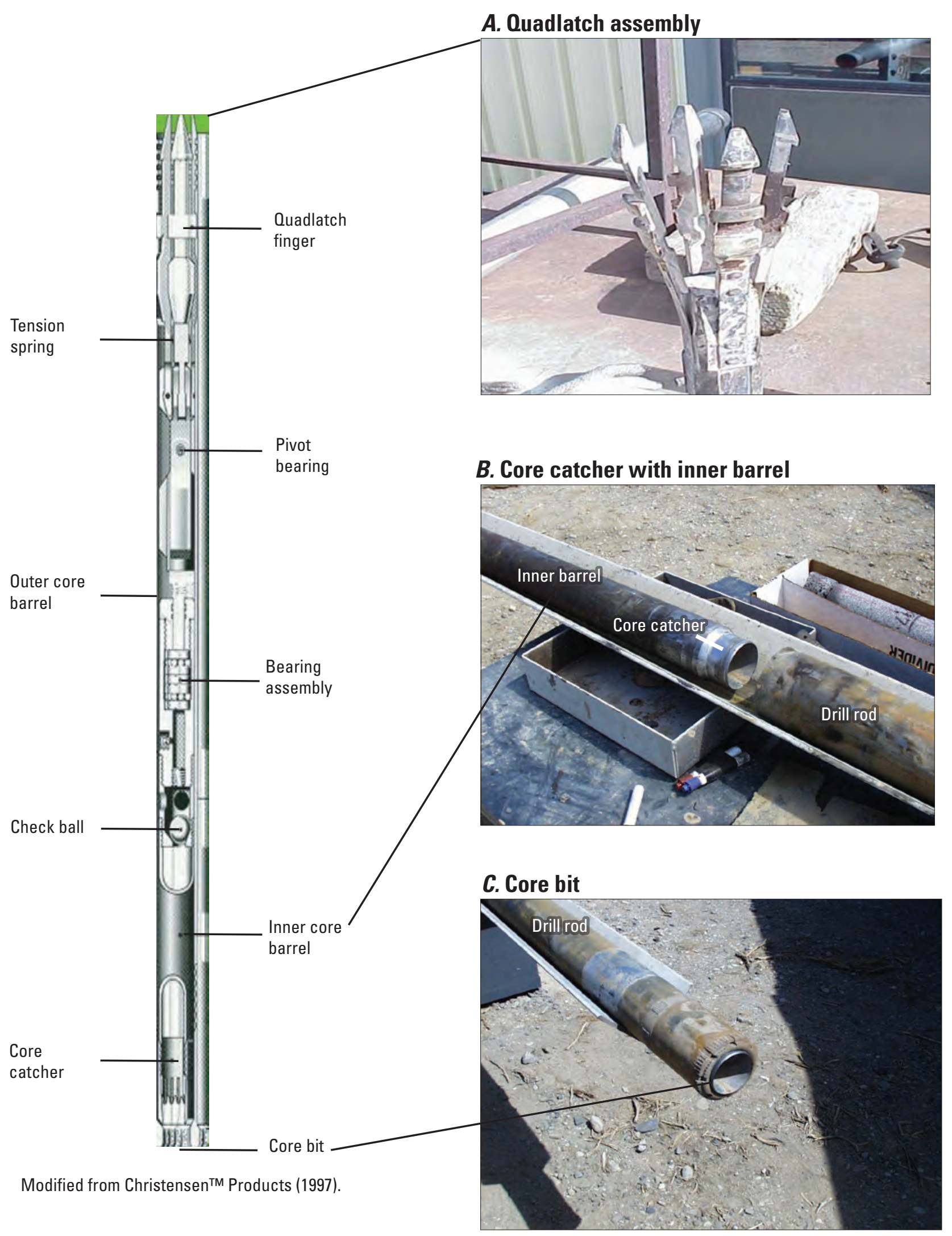

Figure 4. PQ-size coring system similar to one used for coring. PQ refers to core rod sizing (drill-bit size about 4.8-in. diameter). 
Water and air usage ranged from 2 to $7 \mathrm{gal} / \mathrm{min}$, with air pressures ranging from 100 to $350 \mathrm{lb} / \mathrm{in}^{2}$. About 18,000 gal of water were used to complete coring in the two boreholes.

Pressurized air, water, and Baroid ${ }^{\circledR}$ Quik-Foam ${ }^{\circledR}$ were used to drill 15-in. and 9.9-in. diameter sections in boreholes TAN-2271 and TAN-2272. The Quik-Foam ${ }^{\circledR}$ was introduced to improve cutting returns to the surface (appendix A). The mixture of water and Quik-Foam ${ }^{\circledR}$ was continuously injected at rates of about $10 \mathrm{gal} / \mathrm{min}$ to remove cutting material and required a separate mixing system. Water and cutting material for the 9.9-in. diameter sections of each borehole were diverted to holding tanks. Both boreholes experienced minor material sluffing after reaming. The 10-in. well casing was installed to depths of $211 \mathrm{ft} \mathrm{BLS}$ (TAN-2271) and $210 \mathrm{ft}$ BLS (TAN-2272). Total completion depths for TAN-2271 and TAN-2272 were measured near $282 \mathrm{ft} \mathrm{BLS}$ and $287 \mathrm{ft}$ BLS, respectively. Below the 10-in. diameter well casings, the boreholes were left as open-hole completions (figs. 5 and 6).

\section{Borehole TAN-2271 Drilling Activity}

Drilling at TAN-2271 started May 20, 2015, and attempts were made to drill to the first basalt contact using 22-in. augers; however, the augers could not penetrate large cobble material at about $20 \mathrm{ft}$ BLS. After pulling auger flights, a modified 17-in. tri-cone was used to continue drilling to the first basalt flow, at about $28 \mathrm{ft} \mathrm{BLS}$. After removing the bit assembly, a 16-in. diameter well casing was placed to a depth of $28 \mathrm{ft}$ on May 26, 2015. Annular space behind the 16-in. diameter well casing was filled with 24 cubic feet $\left(\mathrm{ft}^{3}\right)$ of dry bentonite.

Core drilling (PQ-size) in TAN-2271 was done in two stages, the first stage involved coring from about 28 to $209 \mathrm{ft}$ BLS (June 2-9, 2015) and the second stage from 209 to $284 \mathrm{ft}$ BLS (June 22-23, 2015). The first competent basalt contact was reached near $33 \mathrm{ft}$ BLS with about $5 \mathrm{ft}$ of mixed basalt rubble with sediment above this contact; surface casing (16-in. diameter) was driven to about $33 \mathrm{ft}$ BLS after coring to $209 \mathrm{ft}$ BLS on June 11, 2015. The second stage of coring from 209 to $284 \mathrm{ft}$ BLS required additional setup to containerize drill cuttings and fluid; however, no circulation returns were brought back to land surface during coring.

Starting July 15, 2015, the previously cored section in borehole TAN-2271 was drilled out to 15 -in. diameter to accommodate 10 -in. diameter well casing and vapor port lines. Drilling the 15-in. diameter borehole section from 33 to $211 \mathrm{ft}$ BLS in TAN-2271 was done July 16-21, 2015. Two stainless-steel vapor port lines (0.38-in. outside diameter) were strapped to 10 -in diameter well casing and lowered to pre-determined depths on July 22, 2015 (fig. 5). The perforated intervals of the shallow and deep vapor lines were set at 133-137 ft and 193-197 ft BLS. The borehole annulus surrounding each 5 - $\mathrm{ft}$ perforated vapor line section was backfilled with 6-9 mesh silica to facilitate vapor flow from the surrounding unsaturated zone. A 50/50 mixture of granulated bentonite and 10-20 mesh-silica sand was placed in the borehole annulus immediately above the 6-9 mesh silica sand. The remainder of the borehole annulus was backfilled with granulated bentonite. The bentonite was installed dry; Izbiki and others (2000) have shown through repeated neutron logging that bentonite hydrates and forms an effective low-permeability seal after installation within the borehole. Frequent sounding measurements along with approximated material volume calculations were used to confirm accurate backfill material placement. Annular material behind 10-in. diameter well casing was examined using natural gamma geophysical logs run before and after material placement. About $24 \mathrm{ft}^{3}$ and $92 \mathrm{ft}^{3}$ of granular bentonite was used to seal the annular space behind the 16-in. and 10-in. diameter well casings, respectively (land surface to $211 \mathrm{ft} \mathrm{BLS}$ ); and about $13 \mathrm{ft}^{3}$ of 6-9 mesh silica sand and $2 \mathrm{ft}^{3}$ of 10-20 mesh silica sand were placed adjacent to, and above, vapor line perforated sections. Annular material was placed July 23, 2015, before drilling resumed.

Between July 27 and July 28, 2015, borehole TAN-2271 was reamed to a 9.9-in. diameter between 211 and $289 \mathrm{ft}$ BLS. While reaming, circulation was lost and borehole cuttings were not returned to the surface; foam (Quik-Foam ${ }^{\circledR}$ ) was added to the drilling fluid to assist in extracting materials from the borehole. About 1,500 gal of drill fluid (water mixed with foam) were returned to surface and diverted to waste boxes for disposal.

After drilling to $289 \mathrm{ft}$ BLS, a borehole video showed a separation between the 9.9-in. diameter drilled hole and PQ-size corehole where the cored section of borehole TAN-2271 was deviated to the side. Prior to setting a submersible pump and measurement line, geophysical logs and borehole video were collected to examine the condition of borehole TAN-2271. The borehole video showed borehole TAN-2271 was open to a depth of $282 \mathrm{ft} \mathrm{BLS}$; however, about $7 \mathrm{ft}$ of drill cuttings had settled to bottom, from 282 to $289 \mathrm{ft}$ BLS.

On August 24, 2015, a temporary Grundfos ${ }^{\mathrm{TM}}$ 5-horsepower stainless steel (SS) submersible pump, 4-wire (7 gauge) pump wire, 1.25-in. diameter SS discharge line, and 1-in. diameter SS water-level line were installed in borehole TAN-2271. The submersible pump intake was set near $273 \mathrm{ft}$ BLS for aquifer testing and well development, and the 1-in. diameter measuring line was installed to $265 \mathrm{ft}$ BLS. The final construction of borehole TAN-2271 (fig. 5) includes (1) 16-in. diameter carbon steel casing extending from land surface to $33 \mathrm{ft}$ BLS, (2) 10-in. diameter threaded carbon steel casing extending from $2 \mathrm{ft}$ above land surface to $211 \mathrm{ft} \mathrm{BLS}$, and (3) 9.9-in. inside diameter open borehole from 211 to $282 \mathrm{ft}$ BLS. Surface completion includes a 4-ft diameter concrete pad complete with a brass survey marker, and a locking wellhead (table 1). 


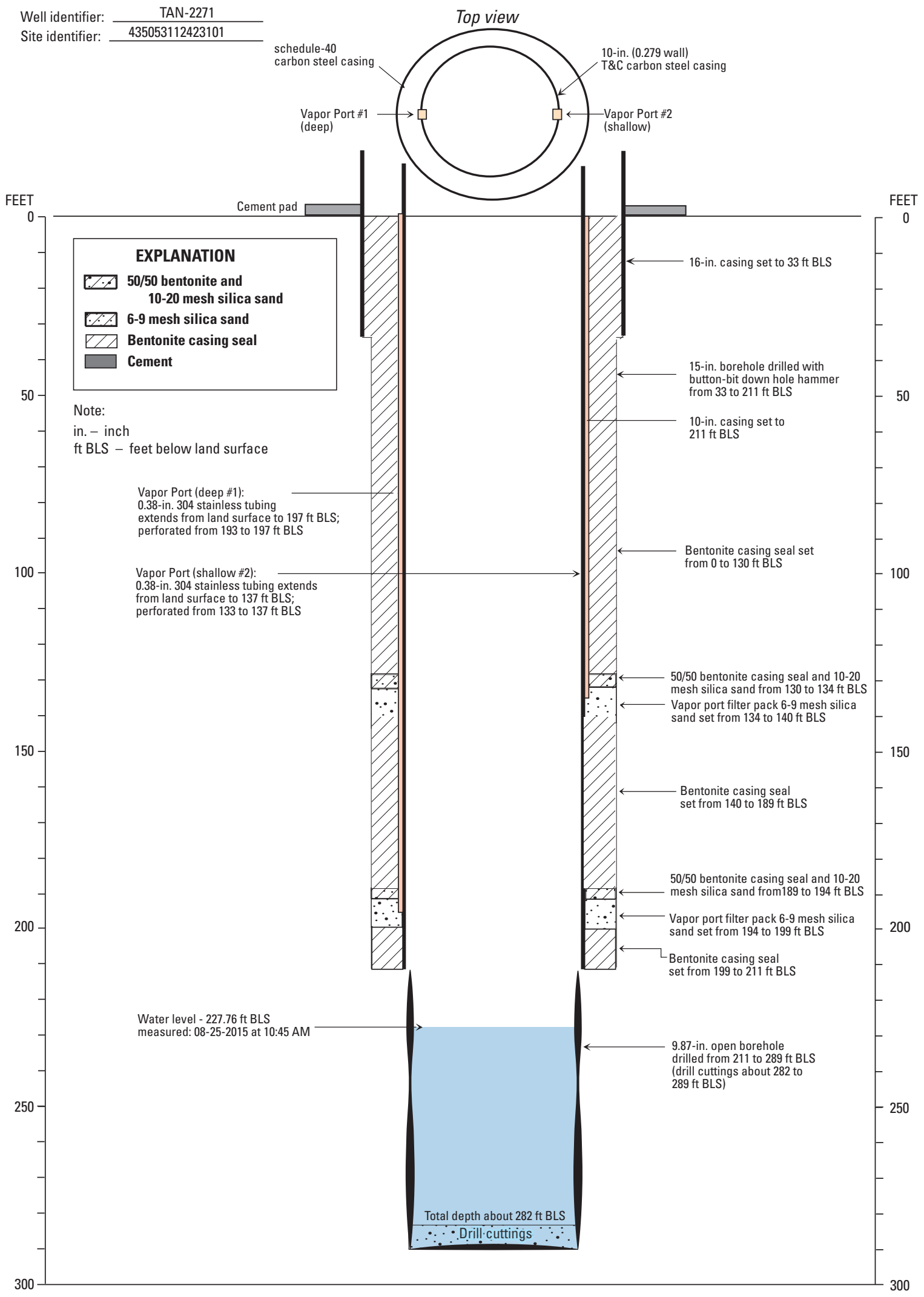

Figure 5. Final constructed borehole TAN-2271, Test Area North, Idaho National Laboratory, Idaho. 
Table 1. Location and completion information for boreholes TAN-2271 and TAN-2272, Test Area North, Idaho National Laboratory, Idaho.

[L ocation and completion information: Site identifier: Unique numerical identifier used to access well data (http://waterdata.usgs.gov/nwis). Longitude, Latitude, and Measurement point elevation: From survey taken at brass survey marker (brass cap) located adjacent to well head on cement pad. Aquifer thickness: Altitude of the base of the aquifer as interpreted from geophysical surveys (Whitehead, 1992) subtracted from the land surface altitude. Open borehole diameter: Based on drilled diameter of open borehole interval. L ocal name: Local well identifier used in this study. Location of boreholes are shown in figure 2. Abbreviations: BLS, below land surface; NAD 27, North American Datum of 1927; NGVD 29, National Geodetic Vertical Datum of 1929; ft, foot; in., inch]

\begin{tabular}{|c|c|c|}
\hline $\begin{array}{l}\text { Location and } \\
\text { completion information }\end{array}$ & \multicolumn{2}{|c|}{ Local name } \\
\hline Site identifier & 435053112423101 & 435053112423001 \\
\hline Latitude & 4350’53.34” (NAD 27) & 4350’52.91” (NAD 27) \\
\hline Measurement point elevation & 4,780.98ft (NGVD 29) & $4,781.25 \mathrm{ft}(\mathrm{NGVD} 29)$ \\
\hline Drill depth & $289 \mathrm{ft}$ BLS & $289 \mathrm{ft}$ BLS \\
\hline Open borehole diameter & 9.9 in. & 9.9 in. \\
\hline Casing diameter & $10 \mathrm{in.}$ & $10 \mathrm{in.}$ \\
\hline Top of open borehole & $211 \mathrm{ft}$ BLS & $210 \mathrm{ft}$ BLS \\
\hline Bottom of open borehole & $282 \mathrm{ft}$ BLS & $287 \mathrm{ft}$ BLS \\
\hline Depth to water & $\begin{array}{l}227.76 \mathrm{ft} \text { BLS, measured August 25, 2015, } \\
\text { at 10:45 a.m. }\end{array}$ & $\begin{array}{l}227.90 \mathrm{ft} \text { BLS, measured August 27, 2015, } \\
\text { at 09:19 a.m. }\end{array}$ \\
\hline
\end{tabular}

\section{Borehole TAN-2272 Drilling Activity}

Drilling at TAN-2272 started May 27, 2015, making use of a 17 -in. modified tri-cone bit to the first basalt contact. Afterwards, the 16-in. diameter well casing was placed in the borehole but stopped short of the bottom, near $24 \mathrm{ft}$ BLS. To advance surface casing to the first basalt contact, a casing hammer with drive plate were connected to the SD-300 rig to advance the 16-in. diameter casing to $31 \mathrm{ft}$ BLS on June 15, 2015. Gravel and cobble size material prevented casing from getting to bottom and drilling was not productive with the caving material above the basalt contact.

Between July 6 and July 13, 2015, borehole TAN-2272 was drilled to 15-in. diameter to a depth of $210 \mathrm{ft}$ BLS. To get drill cuttings returned to the surface, Quik-Foam ${ }^{\circledR}$ was added to drilling fluids to assist in extracting cutting material from the borehole, and attempts were made to divert cuttings at land surface through a diverter. After reaching $210 \mathrm{ft}$ BLS, the 10 -in. diameter casing was set in the borehole.

Two stainless-steel vapor port lines (0.38-in. outside diameter) were strapped to 10 -in. diameter casing and lowered to pre-determined depths on July 15, 2015 (fig. 6). The bottom 5 - $\mathrm{ft}$ of the vapor line were perforated; the perforated intervals of the shallow and deep vapor lines were set at 133 to $137 \mathrm{ft}$ and 193 to $197 \mathrm{ft}$ BLS. The borehole annulus surrounding each 5 - $\mathrm{ft}$ perforated vapor line section was backfilled with 6-9 mesh silica to facilitate vapor flow from the surrounding unsaturated zone. A 50/50 mixture of granulated bentonite and 10-20 mesh-silica sand was placed in the borehole annulus immediately above the 6-9 mesh silica sand. The remainder of the borehole annulus was backfilled with granulated bentonite. Frequent sounding measurements along with approximated material volume calculations were used to confirm accurate backfill material placement. Annular material behind 10-in. diameter well casing was examined using natural gamma geophysical logs run before and after material placement. About $7.5 \mathrm{ft}^{3}$ and $85 \mathrm{ft}^{3}$ of granular bentonite was used to seal the annular space behind the 16-in. and 10-in. diameter well casings, respectively (land surface to $210 \mathrm{ft}$ BLS); and about $14.5 \mathrm{ft}^{3}$ of 6-9 mesh silica sand and $1 \mathrm{ft}^{3}$ of 10-20 mesh silica sand were placed adjacent to, and above, vapor line perforated sections. Annular material was placed July 22, 2015, before drilling resumed.

Core drilling (PQ-size) in TAN-2272 was completed once 10-in. diameter well casing was set to $210 \mathrm{ft}$ BLS, coring from 210 to $282 \mathrm{ft}$ BLS was done between July 28 and July 30, 2015. Coring from 210 to $282 \mathrm{ft}$ BLS required additional setup to containerize drill cuttings and fluid; however, no circulation material was brought back to land surface during coring.

Between August 10 and August 13, 2015, borehole TAN-2272 was reamed to a 9.9-in. diameter between 210 and $289 \mathrm{ft}$ BLS. While reaming, the borehole was not cleaning and required foam (Quik-Foam ${ }^{\circledR}$ ) to assist with extracting rock cuttings from the borehole. Drill fluid that returned to the surface was diverted to waste boxes for disposal. About $1,800 \mathrm{gal}$ of fluid with cuttings was returned to the surface and placed in waste boxes and disposed of through WGS. 


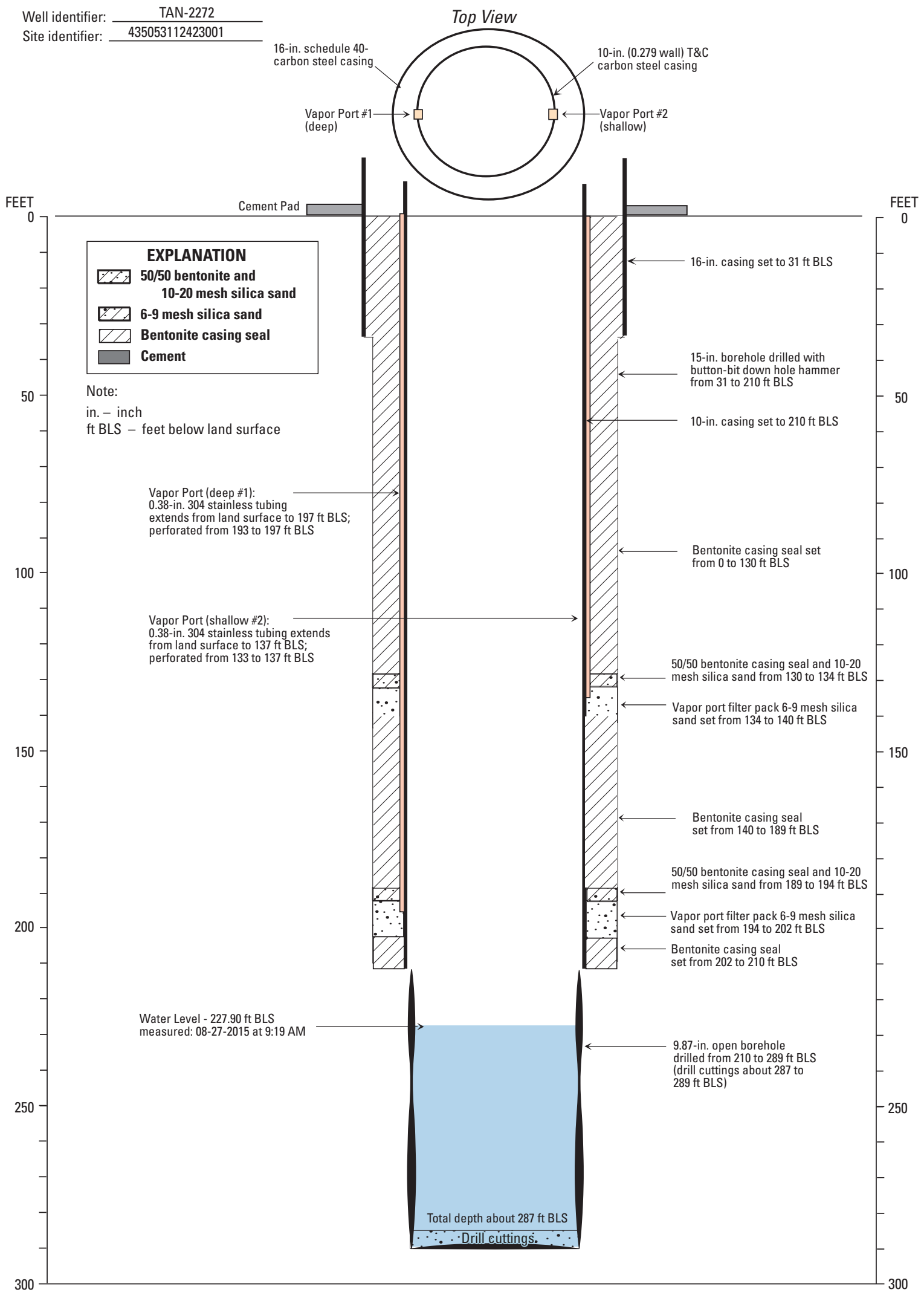

Figure 6. Final constructed borehole TAN-2272, Test Area North, Idaho National Laboratory, Idaho. 
After drilling to $289 \mathrm{ft}$ BLS, a borehole video and geophysical data were collected prior to placing a submersible pump and water-level access line. The borehole video showed the borehole was open to a depth of $287 \mathrm{ft} \mathrm{BLS}$, with $2 \mathrm{ft}$ of drill cutting material (sluff) from 287 to $289 \mathrm{ft}$ BLS. On August 26, 2015, borehole TAN-2272 was configured with a temporary Grundfos ${ }^{\mathrm{TM}} 5$-horsepower SS submersible pump, 4-wire (7 gauge) pump wire, 1.25-in. diameter SS discharge line, and 1-in. diameter SS water-level line. The submersible pump intake was set near $273 \mathrm{ft}$ BLS for aquifer testing and well development, and the 1-in. diameter measuring line was installed down to about $265 \mathrm{ft}$ BLS. The final construction of borehole TAN-2272 (fig. 6) includes (1) 16-in. diameter carbon steel casing extending from land surface to $31 \mathrm{ft}$ BLS, (2) 10-in. diameter threaded carbon steel casing extending from $3 \mathrm{ft}$ above land surface to $210 \mathrm{ft} \mathrm{BLS}$, and (3) 9.9-in. inside diameter open borehole from 210 to $287 \mathrm{ft}$ BLS. Surface completion includes a 4 -ft diameter concrete pad complete with a brass survey marker, and a locking wellhead (table 1).

\section{Geologic and Geophysical Data}

Geologic data were collected and analyzed from core material to provide rock and sediment properties; additionally, geologic and hydrologic data, including geologic contacts, were interpreted from geophysical logs collected and analyzed for boreholes TAN-2271 and TAN-2272. Geophysical logs provide a complete and continuous formation representation adjacent to the well bore and offer more consistency when selecting depths for geologic contacts, when core recovery is sometimes incomplete and subject to damage during the drilling. Boreholes TAN-2271 and TAN-2272 were drilled about $63 \mathrm{ft}$ apart (fig. 2) and have similar geologic features, as interpreted from geophysical logs. Available core from boreholes TAN-2271 and TAN-2272 were photographed and labeled to provide detailed lithologic descriptions from 33 to $284 \mathrm{ft}$ BLS in TAN-2271 and from 210 to $282 \mathrm{ft}$ BLS in TAN-2272. Core photographs and lithologic logs are shown in appendix B.

The geophysical logging equipment operated by the USGS in boreholes TAN-2271 and TAN-2272 provided a select suite of conventional geophysical logs; additionally, borehole video logs were recorded to evaluate the condition of the boreholes after construction. Geophysical logs included natural gamma, neutron, gamma-gamma dual density, caliper, temperature, specific conductance, and electromagnetic flow meter (EMFM), and formation resistivity logs. Additionally, gyroscopic deviation surveys were collected to determine the direction and magnitude of borehole deviation after the boreholes were completed. Geophysical logs, except EMFM station measurements, were collected and saved as electronic files in the form of physical measurement and depth at 0.2-ft depth intervals. EMFM station data were collected at discrete depth locations in open borehole sections between 230 and $280 \mathrm{ft}$ BLS in boreholes TAN-2271 and TAN-2272. Geophysical and borehole video logs were collected during various phases of the drilling process. Using WellCAD ${ }^{\mathrm{TM}}$ software, a synergistic approach was used to display geophysical data and to determine geologic and hydrologic characteristics from these data. The geophysical and video log data are summarized in table 2 . Raw geophysical data are available upon request through the USGS INL Project Office (http://id.water.usgs.gov/INL/).

\section{Geology}

The land surface at boreholes TAN-2271 and TAN-2272 is sparsely vegetated loess. In both boreholes, surficial sedimentary materials include loess exposed at the surface and unconsolidated mixtures of sand, gravel, and cobble materials to the top of the first basalt contact at about $32 \mathrm{ft} \mathrm{BLS}$. Unconsolidated sedimentary materials were described based on drill cuttings observed while drilling and driving 16-in. diameter surface casing to the top of the uppermost basalt flow (figs. 7 and 8; appendix B).

Excluding surficial sediment, three sediment layers were observed between 33 and $284 \mathrm{ft}$ BLS in borehole TAN-2271 (fig. 7); no sediment layers were observed between 210 and $284 \mathrm{ft}$ BLS in borehole TAN-2272 (fig. 8). Including surficial sediment, sediment constitutes less than 1 percent by volume (0-289 ft BLS) of boreholes TAN-2271 and TAN-2272. In borehole TAN-2271, excluding surficial sediment, the thickness of the individual sediment layers were estimated at $1 \mathrm{ft}$ or less. Sediment layers recovered in TAN-2271 appear to be mostly fine sand, silt, and clay.

Upon inspection of core and geophysical data, about 20 basalt flows were observed in borehole TAN-2271 (fig. 7 and appendix B). Basalt texture for borehole TAN-2271 varied between aphanitic, phaneritic, diktytaxitic, and porphyritic. In general, the basalts are medium to dark gray in color. Basalt flows in borehole TAN-2271 ranged in thickness from less than 2 to $78 \mathrm{ft}$ and varied from massive to highly fractured, with high to low vesiculation. Detailed core descriptions and photographs for borehole TAN-2271 (33-284 ft BLS) and for borehole TAN-2272 (210-284 ft BLS), are included in appendix B.

\section{Geophysical Logs}

Geophysical data were collected using Century Geophysical Corporation ${ }^{\mathrm{TM}}$ logging equipment, and the resulting data files were processed using WellCAD ${ }^{\mathrm{TM}}$ analytical software. Borehole video logs were recorded using an Aries Industry ${ }^{\mathrm{TM}}$ WC-1750 downhole color camera. The USGS calibrates geophysical logging equipment annually or as needed; logging equipment sensor uncertainty is specified in table 2. 
Table 2. Geophysical and video log data collected at boreholes TAN-2271 and TAN-2272, Test Area North, Idaho National Laboratory, Idaho.

[Geophysical data presented in this report were collected using one or more of the following logging tools listed below. L og type: Description of geophysical log trace presented. Local name: Local well identifier used in this study. Tool identifier: Century Geophysical Corporation ${ }^{\mathrm{TM}}$ tool number as referenced on Web site http://www.century-geo.com/, WC-1750 camera designed by Aries ${ }^{\mathrm{TM}}$ Industry. Depth: Refers to logging depth reported from land surface measurement point. Date and Time: Refers to date and local time the log was time stamped in month-day-year and in hours and minutes. Sensor uncertainty: Uncertainty specified by tool manufacturer. Comments: Explanations where needed. PQ, core rod sizing (drill-bit size about 4.8-in. diameter). A bbreviations: BLS, below land surface; NA, not applicable; in, inch; ft, foot; ft/min, feet per minute; gal/min, gallon per minute]

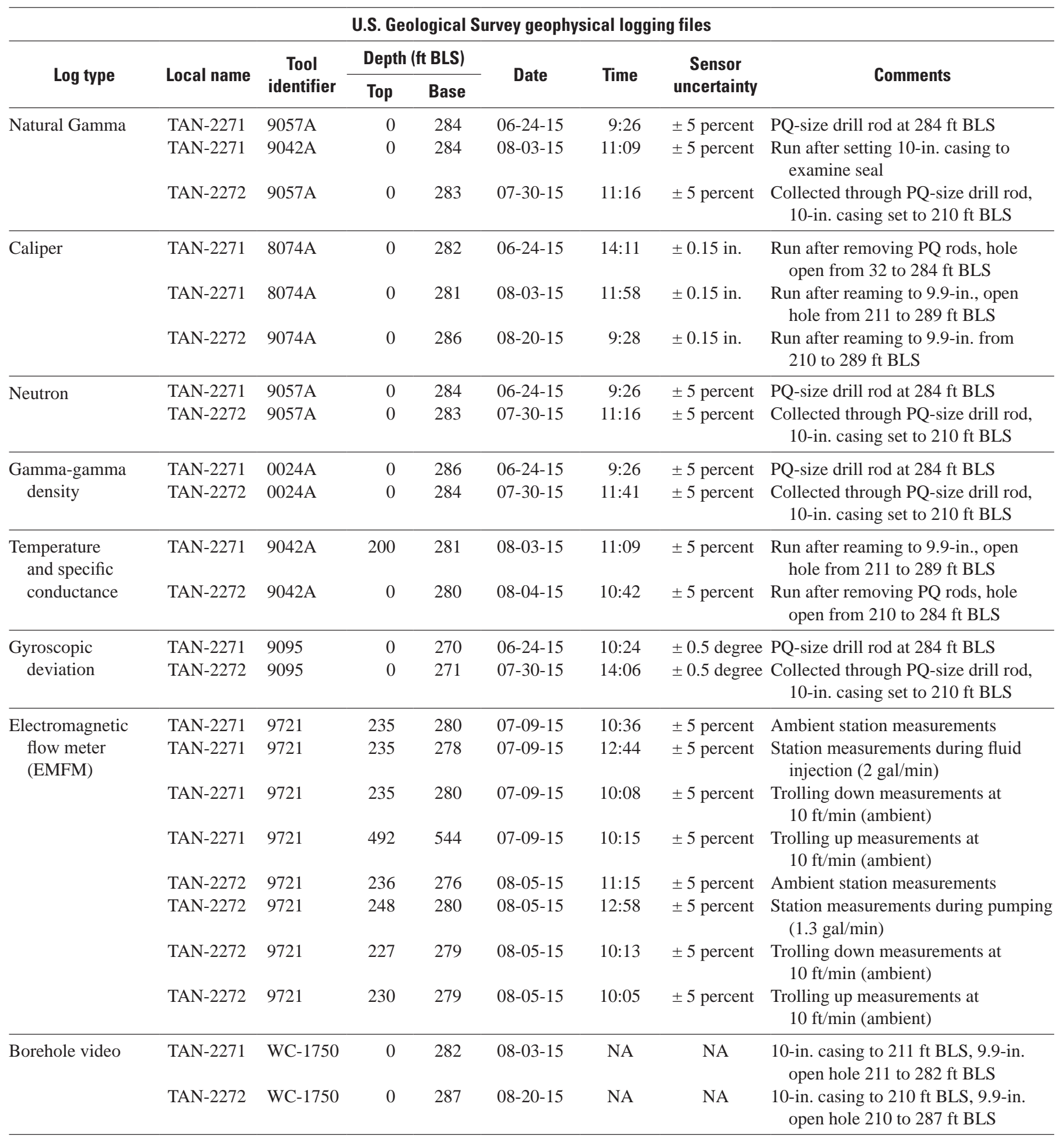




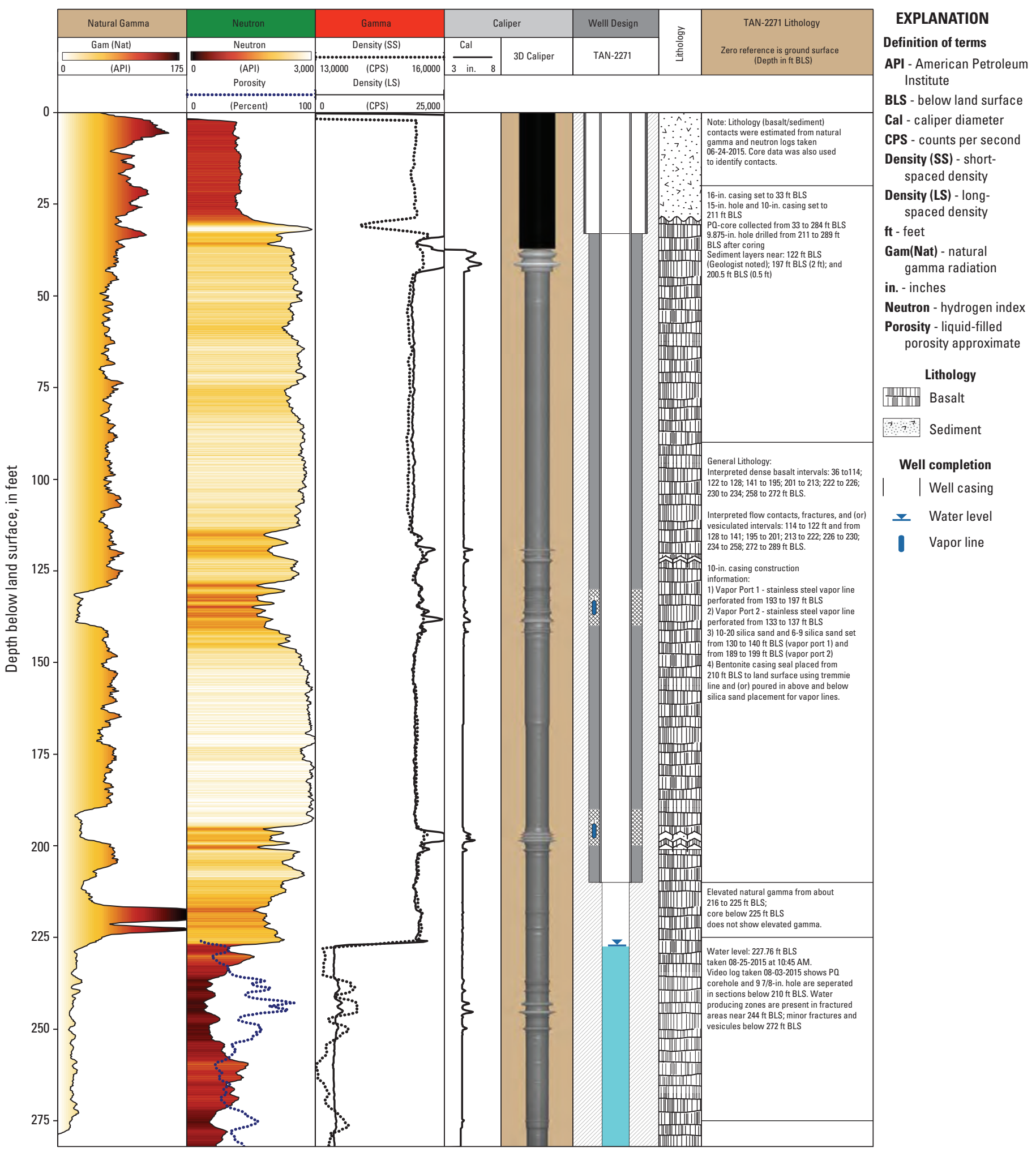

Figure 7. Logs run from total depth to land surface and lithologic logs described from cores, video logs, and geophysical logs for borehole TAN-2271, Test Area North, Idaho National Laboratory, Idaho. 
Geologic and Geophysical Data

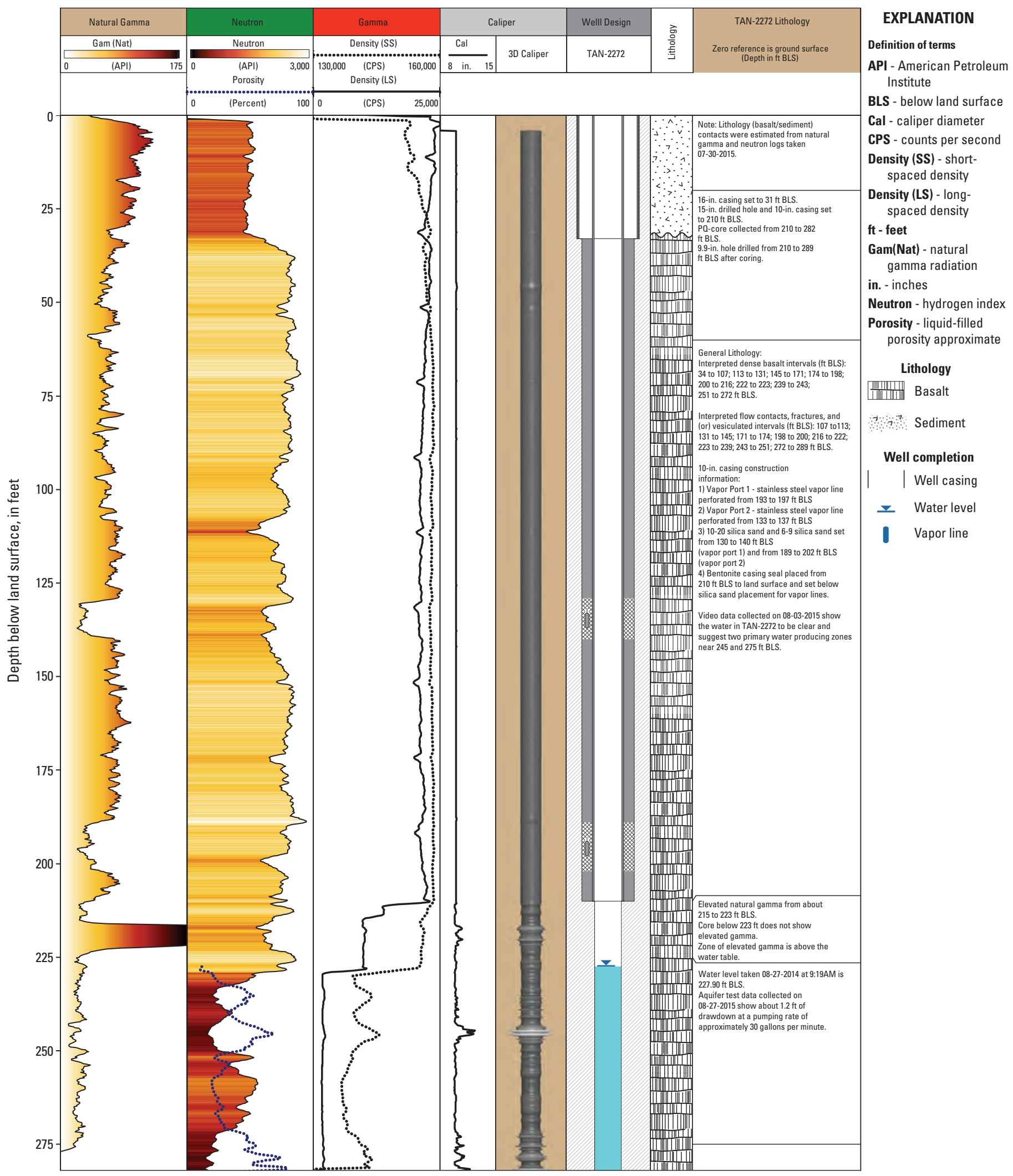

Figure 8. Logs run from total depth to land surface and lithologic logs described from cores, video logs, and geophysical logs for borehole TAN-2272, Test Area North, Idaho National Laboratory, Idaho. 
Wireline geophysical logs and borehole video logs were collected at multiple stages during drilling and construction of boreholes TAN-2271 and TAN-2272 (fig. 9). A composite of natural gamma, neutron, and gamma-gamma dual density, and caliper logs along with well design and general lithology from land surface to completion depth are shown in figures 7 and 8. Attempts were made to describe the condition and drilled diameter of the borehole during each logging stage:

- Stage 1. In borehole TAN-2271, geophysical logs were collected after PQ-core drilling, through the drill rod, from land surface to $284 \mathrm{ft}$ BLS, where the drilled diameter was $4.8 \mathrm{in}$.

- Stage 2. In borehole TAN-2271, geophysical logs were collected after removing PQ-core rods from land surface to $284 \mathrm{ft}$ BLS, where the drilled diameter was 4.8 in.
- Stage 3. In borehole TAN-2272, geophysical logs were collected after drilling to completion depth; logs were collected through the PQ-size drill rod in borehole TAN-2272, where the drilled borehole diameter was 4.8 in. between 210 and $284 \mathrm{ft}$ BLS. During stage 3, 10-in. diameter well casing and annular seal extended from land surface to $210 \mathrm{ft}$ BLS.

- Stage 4. In boreholes TAN-2271 and TAN-2272, select geophysical logs were collected after final construction to $289 \mathrm{ft}$ BLS; borehole diameter for open-hole sections was approximately 9.9-in. EMFM logs were collected within the open borehole after coring to completion depth in 4.8-in. diameter boreholes in TAN-2271 and TAN-2272. Borehole videos were collected in TAN-2271 and TAN-2272 to review final construction and completion information before well pumps were installed.
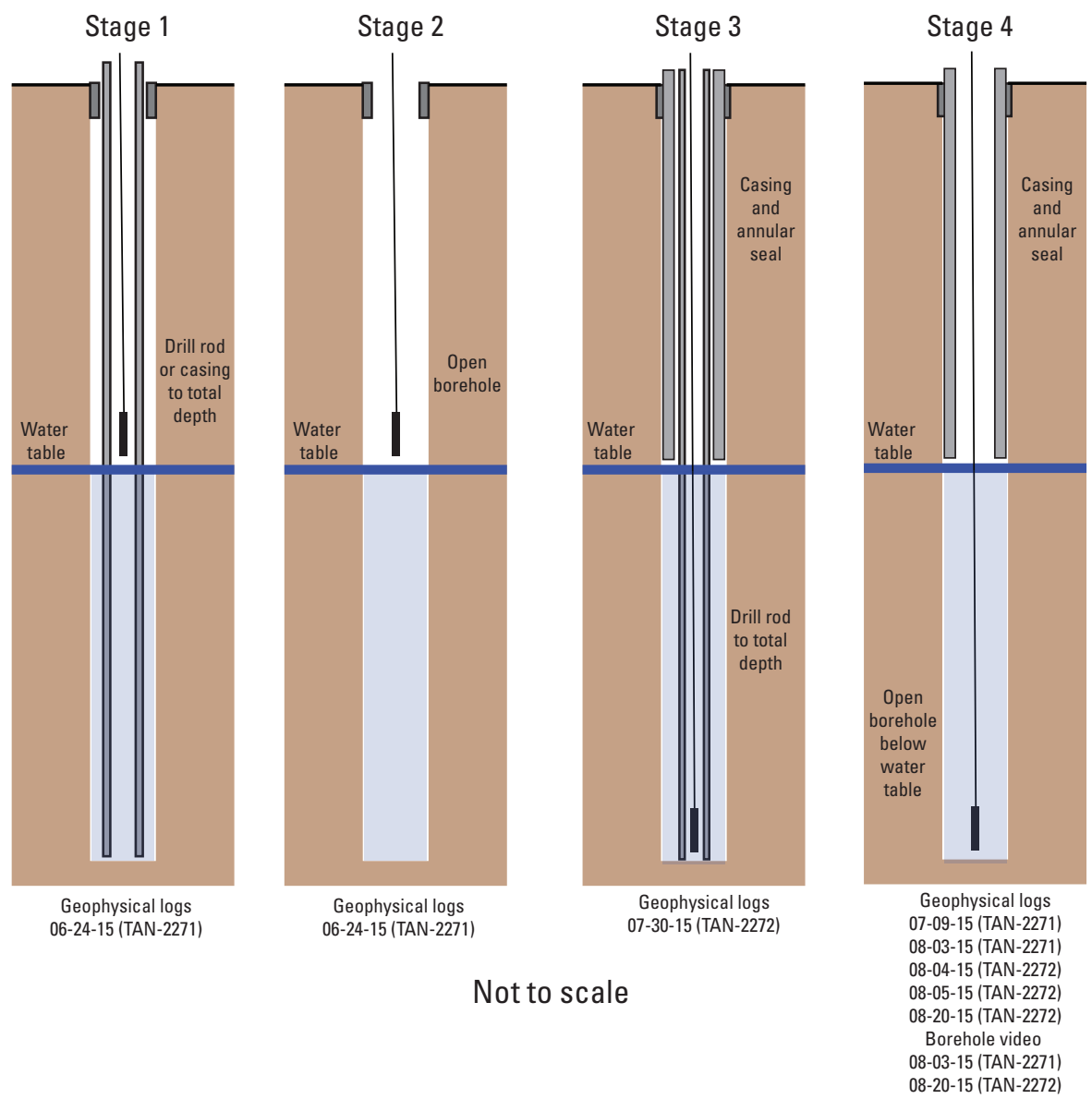

Figure 9. Drilling and construction stages in which geophysical logging was done for boreholes TAN-2271 and TAN-2272, Test Area North, Idaho National Laboratory, Idaho. 


\section{Natural Gamma Logs}

Natural gamma logs record gamma radiation emitted by naturally occurring radioisotopes. The USGS uses these logs at the INL to identify sedimentary layers in boreholes and to distinguish between basalt flows that contain different amounts of potassium-40. The natural gamma detector measures total gamma radiation without distinguishing between individual contributions of the various isotopes.

Natural gamma logs were collected during stages 1 , 3, and 4 (figs. 7 and 8) and collected after placement of the bentonite annular seal (stage 4). Excluding surface sediment, the tops of sediment layers were observed at about 122, 197, and $201 \mathrm{ft}$ BLS in borehole TAN-2271 (appendix B); no sediment layers were observed for TAN-2272. The natural gamma logs do not appear to distinguish between the basalt flows and sediment layers in borehole TAN-2271; however, boreholes TAN-2271 and TAN-2272 show a decreased natural gamma signature adjacent to perforated vapor line sections after setting casing, near 135 and $195 \mathrm{ft}$ BLS (figs. 7 and 8). The decreased natural gamma reflects the change from bentonite casing seal to sand, where bentonite registers higher gamma radiation readings. Additionally, elevated natural gamma between 216 and $225 \mathrm{ft}$ BLS in borehole TAN-2271 and from 215 to $223 \mathrm{ft}$ BLS in borehole TAN-2272 suggest the location of radionuclides in basalt (figs. 7 and 8). The presence of elevated gamma radiation readings were confirmed by physical measurements after core material was brought to land surface using a portable Geiger counter survey meter.

\section{Caliper Logs}

Down-hole caliper logging tools measure the inside diameter of the open borehole. The caliper tool generates a continuous log of the borehole diameter by using three extendable, spring-loaded arms that press against the sides of the borehole and detect changes in the diameter as the tool is raised from the bottom of the borehole. The caliper tool can detect changes in borehole diameter greater than or equal to 0.15 in.

Open-hole caliper logs were collected during stage 2 in borehole TAN-2271 and stage 4 in borehole TAN-2272 (figs. 7 and 8). Caliper logs were used to confirm rock property changes such as fractured and (or) vesicular to dense basalt. In addition, the caliper logs was used to determine the quantity of sand and grout needed to fill the annular space during borehole construction. Fractured and (or) vesicular zones, identified in caliper logs, correlate with elevated neutron porosity data and changes in density for boreholes TAN-2271 and TAN-2272 (figs. 10 and 11). About 50 percent of the basalt identified in boreholes TAN-2271 and TAN-2272 is considered dense and the other 50 percent is considered fractured and (or) vesicular basalt. Dense basalt appears to separate fractures located at the water table and near the bottom of boreholes TAN-2271 and
TAN-2272. Fractures and vesiculated zones are considered the primary water producing zones where groundwater flow is expected.

\section{Neutron Logs}

Neutron measurements are a general indicator of hydrogen content; when they are combined with natural gamma logs for sediment location, they can be used to identify perched groundwater zones in the unsaturated zone. The neutron log records the continuous measurement of the induced radiation produced by bombarding surrounding media (casing, formation, and fluid) with fast neutrons (energies greater than $10^{5}$ electron volts from a sealed neutron source, which collide with surrounding atomic nuclei until they are captured (Keys, 1990, section 5, p. 95). The neutron tool used by the USGS INL Project Office has an americium/ beryllium neutron source and a Helium-3 detector that counts slow (thermal) neutrons (those that have energies less than 0.025 electron volts).

Neutron logs were collected during stages 1 and 3 (fig. 9) with casing extended to bottom of the boreholes. Review of the neutron data indicated no evidence of perched groundwater in the unsaturated zone (land surface to about $228 \mathrm{ft}$ BLS). Neutron logs were examined for the open-hole section of aquifer to identify areas of high and low hydrogen content in boreholes TAN-2271 and TAN-2272 (figs. 10 and 11). A color gradient, ranging from red (higher hydrogen content) to white (lower hydrogen content), was applied to approximate the location of water-producing zones in figures 10 and 11 . The neutron logs show good agreement with PQ-core collected from boreholes TAN-2271 and TAN-2272 (figs. 10 and 11), where areas of low hydrogen content correlate with areas of dense and massive basalt, and areas of high hydrogen content correlate with areas of fractured and vesicular basalt. On the basis of basalt-hydrogen correlations, neutron logs show evidence for fractured and vesicular basalt, indicative of more productive water-producing zones, within the open-hole intervals at these depths: (1) borehole TAN-2271, depths 235-253 and 272-282 ft BLS; (2) borehole TAN-2272, depths 232-251 and 272-282 ft BLS (figs. 10 and 11).

\section{Gamma-Gamma Dual Density Logs}

The principle behind density logging is the detection of Compton-scattered gamma rays that originate from a small radioactive source. The intensity of the gamma radiation reflected back to the probe is primarily a function of electron density of the media after it is backscattered or absorbed in a drill hole, borehole fluid, or surrounding media. The type of density probe used for this investigation is the omni-directional, dual detector sonde that responds to density variation in counts per second (CPS), registering higher CPS counts for lower density material. 


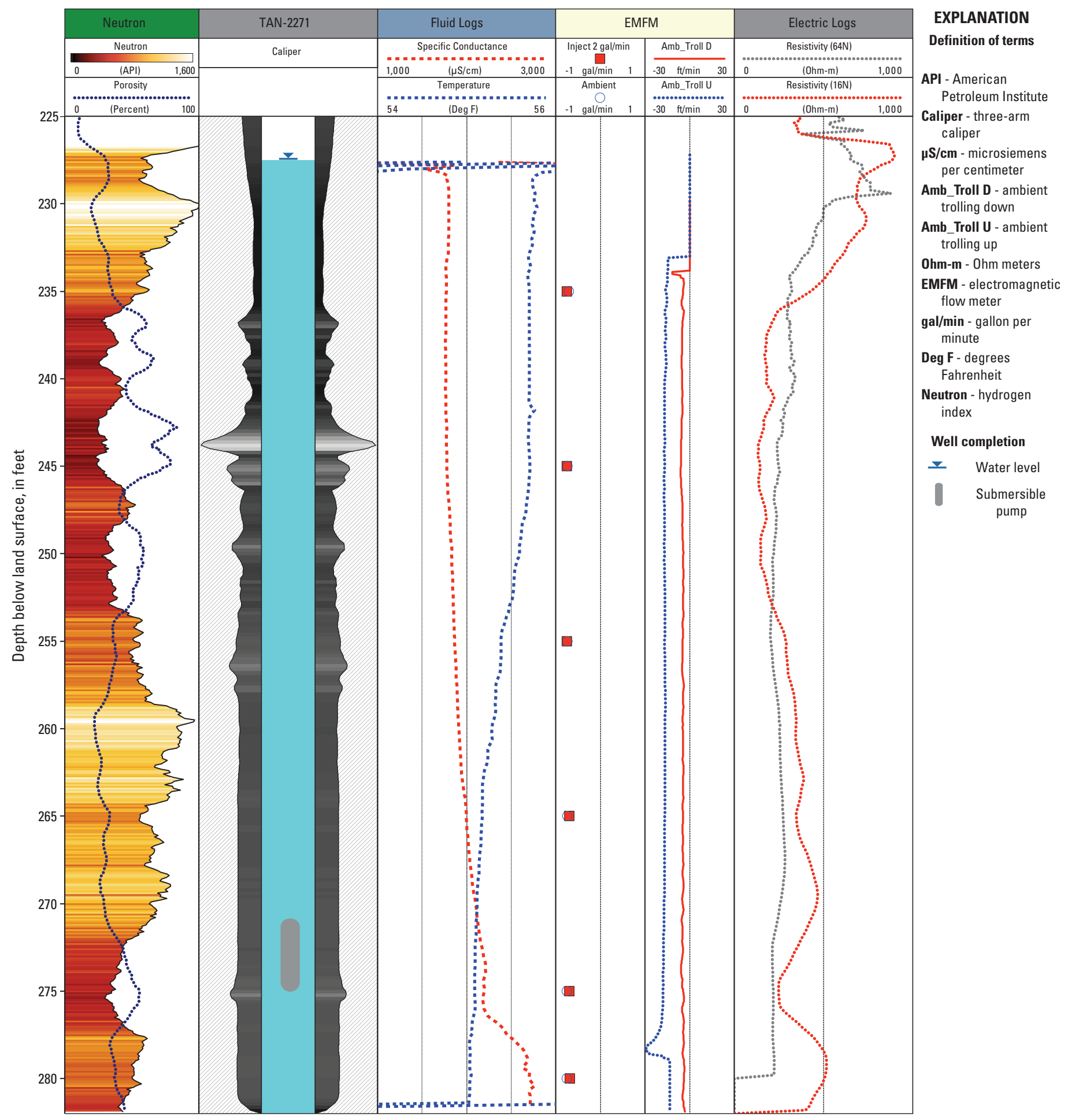

Figure 10. Expanded geophysical and lithologic logs with focus on depths 225-282 feet below land surface for borehole TAN-2271, Test Area North, Idaho National Laboratory, Idaho. 
Geologic and Geophysical Data

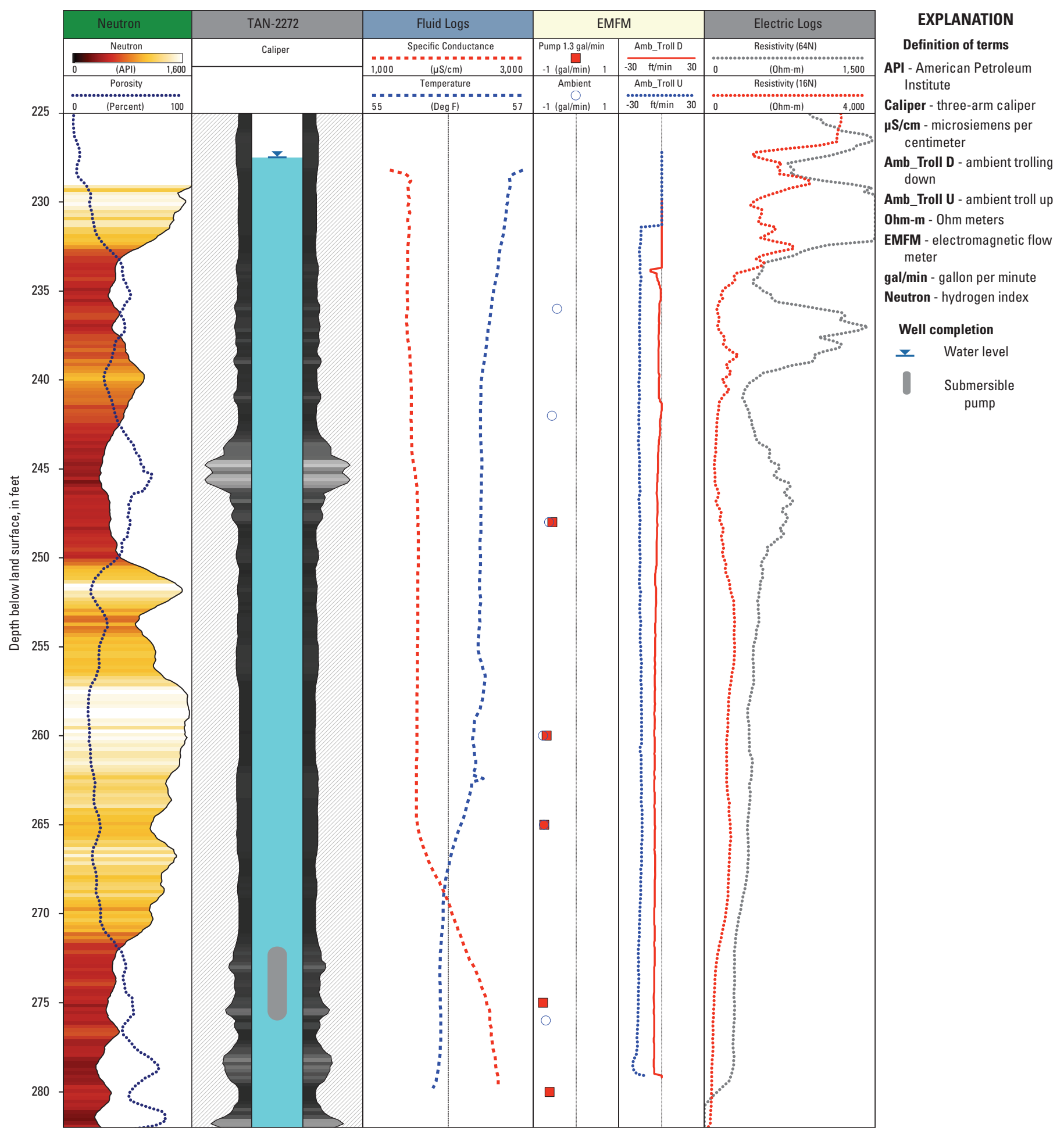

Figure 11. Expanded geophysical and lithologic logs with focus on depths 225-282 feet below land surface for borehole TAN-2272, Test Area North, Idaho National Laboratory, Idaho. 
Gamma-gamma dual density logs were collected during stage 1 in borehole TAN-2271 and during stage 3 in borehole TAN-2272 (figs. 7, 8, and 9). Density logs were used to identify areas of dense, as opposed to fractured, basalt. Synergistically, the location of fracture zones indicated by gamma-gamma logs are consistent with zones indicated by other geophysical methods.

\section{Fluid Logs}

Fluid specific conductance and temperature were measured during stage 4 in boreholes TAN-2271 and TAN-2272 (fig. 9). Specific conductance and temperature were measured in the saturated part of the borehole, after the boreholes had about 5 days to stabilize from drilling activity. Specific conductance measures the ability of a fluid to conduct electric current; changes in specific conductance are generally related to amount of dissolved solids in a fluid. Specific conductance and temperature provide a general indicator for changing water chemistry and (or) can indicate where groundwater is contributed through fractures and (or) sediments to a borehole in a basalt-sediment aquifer system.

Specific conductance in boreholes TAN-2271 and TAN-2272 ranged from about 1,780 to 2,760 microsiemens per centimeter $(\mu \mathrm{S} / \mathrm{cm})$ and 1,530 to $2,590 \mu \mathrm{S} / \mathrm{cm}$, respectively (figs. 10 and 11). Specific conductance increases in both boreholes at the fracture near $275 \mathrm{ft}$ BLS in TAN-2271 and near $268 \mathrm{ft} \mathrm{BLS}$ in TAN-2272, where the specific conductance increases about 800-900 $\mu \mathrm{S} / \mathrm{cm}$.

Water temperature in boreholes TAN-2271 and TAN-2272 ranges from about 55.8 to $56.7^{\circ} \mathrm{F}$ in both boreholes. Temperature data suggest that groundwater within the fluid column is slightly cooler at about the same depth where specific conductance is increasing. Specific conductance is much higher in the lowest productive zones and suggest a change in aquifer chemistry near this level for both wells.

\section{Electric Logs}

Electric logs for boreholes TAN-2271 and TAN-2272 were collected during stage 4 . These electric logs include normal resistivity logs (16-in. normal and 64-in. normal). The normal-resistivity logs record the electrical resistivity of the surrounding rocks and groundwater as measured by variably spaced potential electrodes, located on the logging probe. Normal resistivity logs were used synergistically to confirm stratigraphic layering in basalt flow units for boreholes TAN-2271 and TAN-2272.

\section{Electromagnetic Flow Meter Logs}

The design of the EMFM is based on Faraday's Law of Induction: voltage induced by a conductor moving at right angles through a magnetic field is directly proportional to the velocity of the moving conductor. Groundwater flow through this magnetic field induces voltage that is measured by electrodes and then used to calculate a volumetric flow rate (Paillet, 2000). EMFM logs are used to identify vertical flow, to establish relative hydraulic gradients, and to identify transmissive fractures and zones. In fractured rock, it is important to conduct EMFM logging under both ambient and stressed conditions where possible, to estimate hydraulic properties (Lane and others, 2002). Station and trolling data were collected from boreholes TAN-2271 and TAN-2272 under ambient and stressed conditions. Station measurements were collected above and below basalt fractures where groundwater flow was anticipated. Both neutron and three-arm caliper logs were used to select locations of station measurements. Trolling measurements were collected while moving the tool at a rate of $10 \mathrm{ft} / \mathrm{min}$ in the down and up directions; trolling rate was not removed from readings (figs. 10 and 11).

EMFM measurements were collected during stage 4 (fig. 9) for boreholes TAN-2271 and TAN-2272, after the boreholes were allowed to stabilize a few days following coring. Ambient and stressed station measurements in each borehole were collected at five or six depths between 230 and $282 \mathrm{ft}$ BLS. Centralized trolling measurements were collected without the use of a rubber diverter; however, for stationary measurements the EMFM was equipped with a rubber diverter and centralizer to direct groundwater flow through the EMFM throat.

EMFM trolling measurements in boreholes TAN-2271 and TAN-2272 start near $233 \mathrm{ft}$ and end near $282 \mathrm{ft}$ BLS, both boreholes show very similar profiles (figs. 10 and 11). Profile flow spikes near the top and bottom of the borehole were the result of starting the tool and adjusting to speed. The fluid column above about $233 \mathrm{ft}$ BLS and below about $282 \mathrm{ft}$ BLS were not measured. EMFM trolling measurements suggest minimal change in velocity for both borehole profiles. The observed shift between the down and up profile events are related to change in tool direction from down to up (figs. 10 and 11).

Stationary measurements in each borehole were collected under ambient and stressed conditions. Stressed conditions in borehole TAN-2271 were achieved by injecting water; stressed conditions in borehole TAN-2272 were achieved by pumping. Injected water for borehole TAN-2271 was supplied by a nearby hydrant. Potable water was allowed to fall freely down the PQ-size casing to the water table. The rate at which water was injected was controlled by a gate valve and the rate was measured manually at about 2 gal/min. For borehole TAN-2272 stressed station measurements, a submersible pump was positioned near $240 \mathrm{ft}$ BLS and measurements were collected after about 30 minutes of pumping at about $1.3 \mathrm{gal} / \mathrm{min}$. Ambient and stressed stationary measurements in boreholes TAN-2271 and TAN-2272 varied only slightly. 
EMFM data collected for boreholes TAN-2271 and TAN-2272 show similar vertical groundwater rates (figs. 10 and 11). Ambient station measurements show downward flow rates ranging from -0.70 to $-0.75 \mathrm{gal} / \mathrm{min}$ and from -0.41 to $-0.64 \mathrm{gal} / \mathrm{min}$ for boreholes TAN-2271 and TAN-2272, respectively (figs. 10 and 11). Stressed station measurements show downward flow rates ranging from -0.71 to $-0.81 \mathrm{gal} / \mathrm{min}$ while injecting $2 \mathrm{gal} / \mathrm{min}$ in TAN-2271and from -0.39 to $-0.69 \mathrm{gal} / \mathrm{min}$ while pumping $1.3 \mathrm{gal} / \mathrm{min}$ in TAN-2272. For boreholes TAN-2271 and TAN-2272, injecting and pumping water suggest minimal change between ambient and stressed conditions.

\section{Gyroscopic Deviation Survey}

Borehole gyroscopic deviation surveys were run during stages 2 and 4 (fig. 9) for boreholes TAN-2271 and TAN-2272, respectively (fig. 12). The gyroscopic deviation survey measures the vertical deviation of a borehole from land surface to the bottom of the hole. Deviation was measured every $0.1 \mathrm{ft}$ and shown in 50-ft increments from 0 to $250 \mathrm{ft}$ BLS. Borehole TAN-2271 indicates a 6.7-ft horizontal deviation at a projected 61.1-degree azimuth at $228 \mathrm{ft}$ BLS. Borehole TAN-2272 indicates a 1.3-ft horizontal deviation at a projected 135.4-degree azimuth at $228 \mathrm{ft} \mathrm{BLS}$. The calculated offsets for boreholes TAN-2271 and TAN-2272 account for horizontal and vertical displacements at various depths; however, at a depth near $228 \mathrm{ft}$ BLS (approximate water table), the calculated offsets (cable depths-true drill hole depths) were -0.10 and $-0.01 \mathrm{ft}$ for boreholes TAN-2271 and TAN-2272, respectively. The USGS uses a water-level correction when the gyroscopic deviation survey suggests the calculated offset exceeds $0.20 \mathrm{ft}$; therefore, no water-level corrections were necessary for boreholes TAN-2271 and TAN-2272. The borehole-deviation measurements are summarized in table 3.

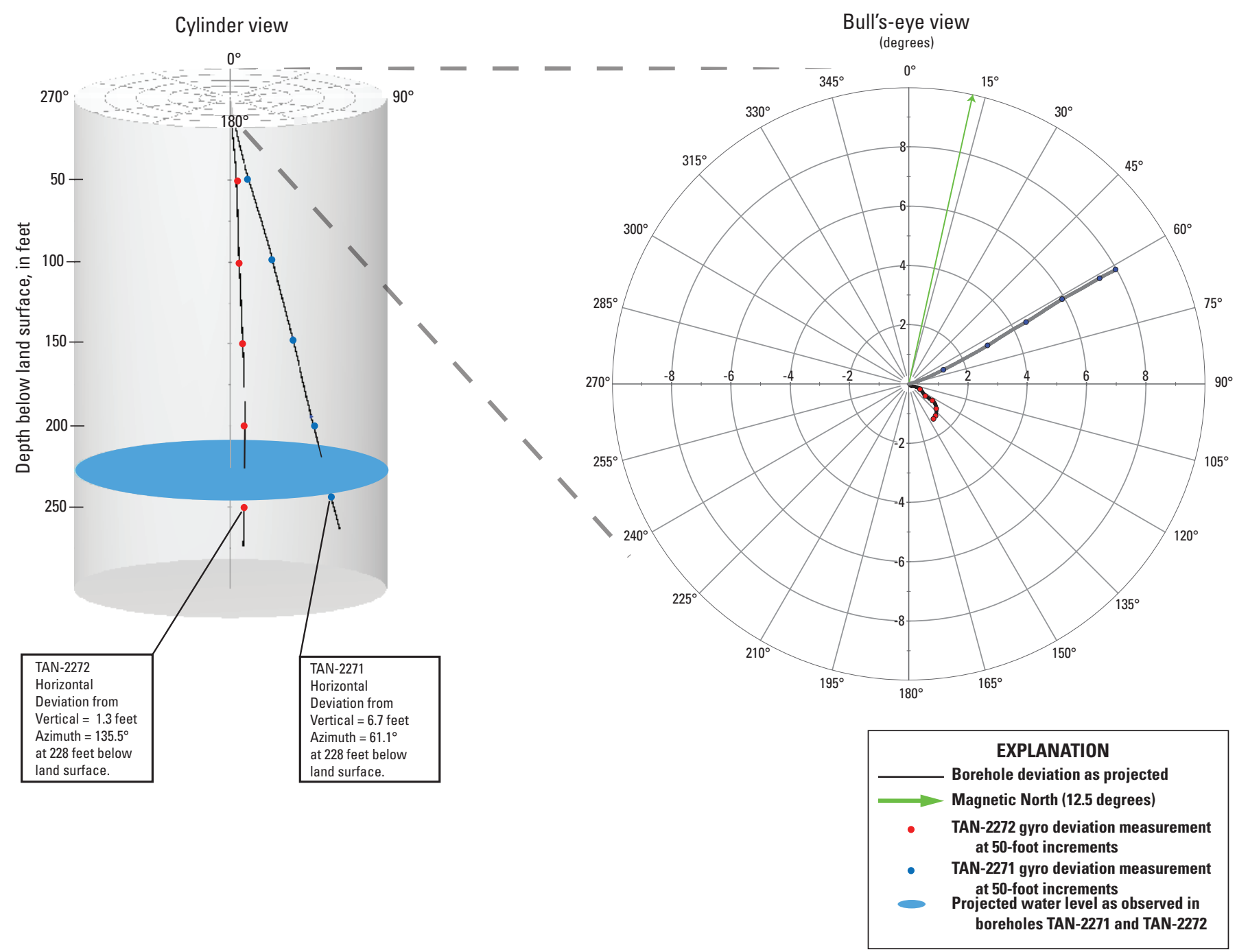

Figure 12. Gyroscopic deviation data collected for boreholes TAN-2271 and TAN-2272, Test Area North, Idaho National Laboratory, Idaho. 
Table 3. Gyroscopic deviation data from processed survey for boreholes TAN-2271 and TAN-2272, Test Area North, Idaho National Laboratory, Idaho.

[Borehole deviation profile shown in figure 12, blue and red circles represent measurements taken at $50 \mathrm{ft}$ increments. Gyroscopic survey performed using a Century Geophysical Corporation ${ }^{\mathrm{TM}} 9095$ logging tool. A tripod was used to hold the tool vertical during warmup and the following information was noted: reference sighting azimuth, land surface drilling datum height, and magnetic declination $=12.46$ degrees. L ocal Name: Local well identifier used in this study. A bbreviations: BLS, below land surface; $\mathrm{ft}$, foot; TDD-CD, true drill depth-cable depth]

\begin{tabular}{rccccc}
\hline Local name & $\begin{array}{c}\text { Cable depth } \\
\text { (ft BLS) }\end{array}$ & $\begin{array}{c}\text { Horizontal } \\
\text { deviation } \\
\text { from vertical } \\
\text { (ft) }\end{array}$ & $\begin{array}{c}\text { True drillhole } \\
\text { depth } \\
\text { (ft) }\end{array}$ & $\begin{array}{c}\text { Calculated offset } \\
\text { (TDD-CD) } \\
\text { (ft) }\end{array}$ & $\begin{array}{c}\text { Drillhole } \\
\text { azimuth } \\
\text { (degrees) }\end{array}$ \\
\hline TAN-2271 & 50 & 1.3 & 49.98 & -0.02 & 67.7 \\
& 100 & 3.0 & 99.95 & -0.05 & 64.0 \\
& 150 & 4.5 & 149.93 & -0.07 & 62.2 \\
TAN-2272 & 5.9 & 199.91 & -0.09 & 61.1 \\
& 1228 & 6.7 & 227.90 & -0.10 & 61.1 \\
& 250 & 7.5 & 249.89 & -0.11 & 61.0 \\
& 50 & 0.4 & 50.00 & 0.00 & 114.7 \\
& 100 & 0.7 & 100.00 & 0.00 & 125.3 \\
150 & 1.0 & 150.00 & 0.00 & 125.3 \\
200 & 1.3 & 200.00 & 0.00 & 131.7 \\
1228 & 1.3 & 227.99 & -0.01 & 135.4 \\
\hline
\end{tabular}

${ }^{1}$ Represents measurement taken near the water table.

\section{Aquifer Test}

Two aquifer tests were conducted at TAN in the ESRP aquifer to define the hydraulic characteristics for boreholes TAN-2271 and TAN-2272. The aquifer test in TAN-2271 was about 3.5 hours, started at 10:47 and ended at 14:15 on August 25, 2015. The aquifer test in TAN-2272 was about 3.7 hours, started at 10:00 and ended at 13:44 on August 27, 2015. Results from these tests were used to determine monitoring well productivity and connectivity between TAN-2271 and TAN-2272. The hydraulic-property estimates were USGS reviewed and recorded in the USGS Groundwater Site Inventory database and data collected during the aquifer test were archived in the USGS Idaho Water Science Center Aquifer Test Archive (appendix C). Aquifer test data and results are available for review upon request.

The aquifer-test data were analyzed for pressure change in response to groundwater pumping and atmospheric conditions. Barometric efficiency was not used to correct water-level data. Wells TAN-2271 and TAN-2272 sustained discharge rates of about $30 \mathrm{gal} / \mathrm{min}$ with total drawdown of about 2 and 1.2 feet, respectively.

\section{Aquifer-Test Procedures}

During the aquifer testing in wells TAN-2271 and TAN-2272, fluid pressure head and temperature were measured continuously and atmospheric pressure was measured periodically. The fluid pressure head $\left(\Psi_{\mathrm{w}}\right)$ and temperature were measured with a Solinst ${ }^{\circledR}$ Levelogger $^{\circledR}$ (F65/M20), a self-contained water level and temperature datalogger suspended on a wireline and located beneath the water table (fig. 13). The datalogger has a stated full scale range of $65.6 \mathrm{ft}$ and accuracy of $\pm 0.032 \mathrm{ft}$, respectively. Atmospheric pressure was monitored at land surface using a handheld barometric sensor and ranged from 12.41 to 12.43 pounds per square inch absolute (psia) during the aquifer test 1 (August 25, 2015) in TAN-2271 and from 12.47 to 12.48 psia during the aquifer test 2 (August 27, 2015) in TAN-2272. Atmospheric pressure data were not used to compensate fluid pressure head because of the short duration of the aquifer tests (less than 4 hours) and relatively small range reported for atmospheric pressure data (less than 0.03 psia). Recovery data were collected but not analyzed.

The flow rate, $Q$, associated with well discharge was monitored periodically using a Blue-White ${ }^{\circledR}$ F-2000 paddlewheel flowmeter sensor (figs. 13 and 14). Measured flow rates remained relatively constant throughout the tests at about $30 \mathrm{gal} / \mathrm{min}$. Estimates of the average pumping rate during the aquifer tests 1 and 2 in TAN-2271 and TAN-2272 were $29.6 \mathrm{gal} / \mathrm{min}$ and $29.8 \mathrm{gal} / \mathrm{min}$, respectively; pumping rates ranged from 28.6 to $30.2 \mathrm{gal} / \mathrm{min}$ during both tests (fig. 14). 

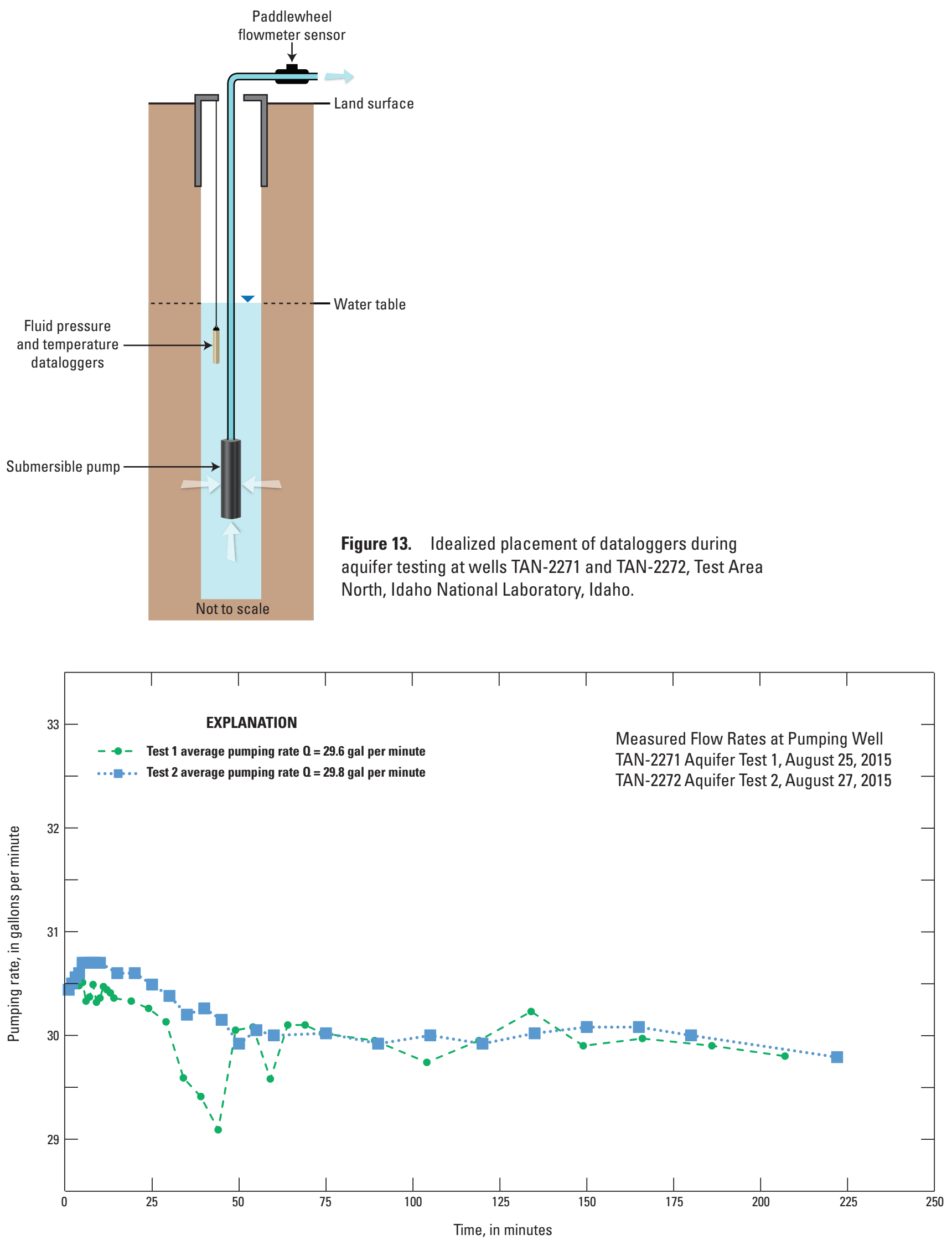

Figure 14. Pumping rates during the aquifer tests at wells TAN-2271 and TAN-2272, Test Area North, Idaho National Laboratory, Idaho. 


\section{Analysis of Aquifer-Test Data}

Aquifer tests were analyzed using the Cooper-Jacob (1946) method. The Cooper-Jacob method is a simplification of the Theis (1935) solution and assumes that the pumping well fully penetrates a confined, homogeneous, isotropic aquifer of infinite extent. Conditions for TAN-2271 and TAN-2272 aquifer testing depart greatly from the Theis (1935) model given that both wells partially penetrate an unconfined heterogeneous anisotropic aquifer. Furthermore, the tests were short in duration (less than 4 hours) where water had to be containerized in holding tanks and discharge volume was limited. The Cooper-Jacob method was used, regardless of the differences between field conditions and theory, because of its simplicity. The Cooper-Jacob method has been used to provide estimates of transmissivity for single-well aquifer tests in unconfined aquifers. The use of this method on unconfined aquifers may overestimate unconfined aquifer transmissivities (Halford and others, 2006).

The Cooper-Jacob method estimates transmissivity by fitting a straight line to drawdowns measured in pumping and observation wells on an arithmetic axis (y) versus time on a logarithmic axis (x). Transmissivity, $\mathrm{T}$, is determined from the slope of the straight line through the use of the following equation:

$$
T=\frac{2.3 Q}{4 \pi} \frac{1}{\Delta s}
$$

where

$$
\begin{aligned}
& \text { Q is the pumping rate, and } \\
& \Delta \mathrm{S} \quad \text { is the drawdown across one log cycle of time } \\
& \text { since the onset of pumping. }
\end{aligned}
$$

The drawdown in the well, $\Delta s$, at any given time, $t$, is determined by subtracting the pressure head at $t$ from the initial pressure head prior to pumping, $\Psi_{0}$. Drawdown as a function of time was calculated using the following equation:

$$
s(t)=\psi_{0}-\psi(t) .
$$

Estimations of horizontal hydraulic conductivity, K, were based on the aquifer thickness, $b$, rather than the screen length, and calculated using equation 3. Halford and others (2006) determined that in most cases using aquifer thickness as the divisor gave better estimates of transmissivity for unconfined aquifers with partial penetration. Aquifer thickness was approximated at $700 \mathrm{ft}$, this estimate is based off interpolated electrical resistivity surveys and data collected from limited deep boreholes at the INL (Whitehead, 1986, sheet 2; Ackerman and others, 2010, fig. 13). Horizontal hydraulic conductivity $(\mathrm{K})$ was calculated using the following equation:

$$
K=\frac{T}{b}
$$

\section{Hydraulic Property Estimates}

The hydraulic properties of the aquifer were defined with $\mathrm{T}$ and $\mathrm{K}$ based on single-well analysis from data collected from the pumping well (fig. 15); additionally, observation well data were collected and analyzed to approximate $T$ and $K$ (fig. 16). The subscripts $1 p$ and $2 p$ are used to designate the aquifer test 1 and 2 pumping well data, respectively; furthermore, the subscripts 10 and 20 are used to designate the aquifer test 1 and 2 observation well data, respectively. The Cooper-Jacob transmissivity was estimated for each test by an interpretive approach; wellbore storage effects can occur during the initial period of the test when water pumped from the well is derived from the wellbore. To eliminate the influence of these effects on this test, the early time responses to pumping (the first 10 minutes of the tests) were not included in the analyses. Electric tape manual measurements were used to verify the transducer data (fig. 15). The Cooper-Jacob method applied to the aquifer test 1 in the pumping and observation wells are shown in figures 15 and 16.

In aquifer test 1 (TAN-2271), $T_{1 p}$ and $K_{1 p}$ were estimated at $4.1 \times 10^{3} \mathrm{ft}^{2} / \mathrm{d}$ and $5.8 \mathrm{ft} / \mathrm{d}$. The observation well data (TAN-2272), $\mathrm{T}_{10}$ and $\mathrm{K}_{10}$ were estimated at $6.2 \times 10^{3} \mathrm{ft}^{2} / \mathrm{d}$ and $8.9 \mathrm{ft} / \mathrm{d}$. Calculations of these parameters using a combination of equations 1 and 3 are:

$$
\begin{aligned}
T_{1 p} & =\frac{2.3 Q_{1}}{4 \pi} \frac{1}{\Delta s_{1 p}}=\frac{2.3 \times 3.95 \mathrm{ft}^{3} / \mathrm{min}}{4 \pi \times 0.26 \mathrm{ft}} \\
& =2.84 \mathrm{ft}^{2} / \min \text { or } 4.1 \times 10^{3} \mathrm{ft}^{2} / \mathrm{d}
\end{aligned}
$$

$$
\begin{aligned}
K_{1 p} & =\frac{T_{1}}{b}=\frac{2.84 \mathrm{ft}^{2} / \mathrm{min}}{700 \mathrm{ft}} \\
& =4.1 \times 10^{-3} \mathrm{ft} / \mathrm{min} \text { or } 5.8 \mathrm{ft} / \mathrm{d}
\end{aligned}
$$

$$
\begin{aligned}
T_{1 o} & =\frac{2.3 Q_{1}}{4 \pi} \frac{1}{\Delta s_{1 o}}=\frac{2.3 \times 3.95 \mathrm{ft}^{3} / \mathrm{min}}{4 \pi \times 0.17 \mathrm{ft}} \\
= & 4.3 \mathrm{ft}^{2} / \mathrm{min} \text { or } 6.2 \times 10^{3} \mathrm{ft}^{2} / \mathrm{d} \\
K_{1 o} & =\frac{T_{1}}{b}=\frac{4.34 \mathrm{ft}^{2} / \mathrm{min}}{700 \mathrm{ft}} \\
& =6.2 \times 10 \mathrm{ft} / \mathrm{min} \text { or } 8.9 \mathrm{ft} / \mathrm{day}
\end{aligned}
$$




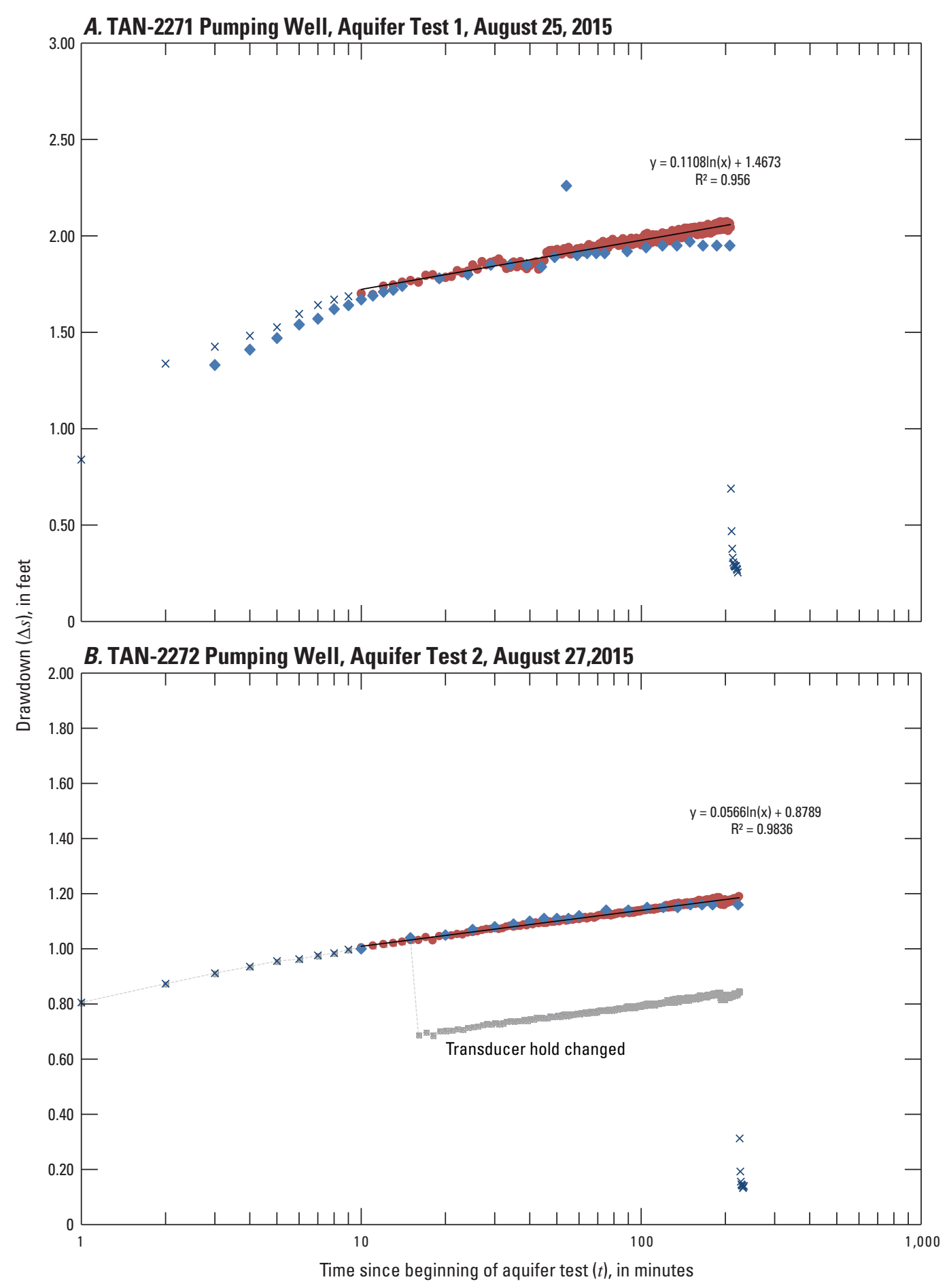

EXPLANATION

- Log (data used)

-... Data not corrected

- Data used

$\times \quad$ Data ignored

- Etape \#4

Figure 15. Aquifer test 1 and 2 pumping well time series for wells $(A)$ TAN-2271 and (B) TAN-2272, Test Area North, Idaho National Laboratory, Idaho. 


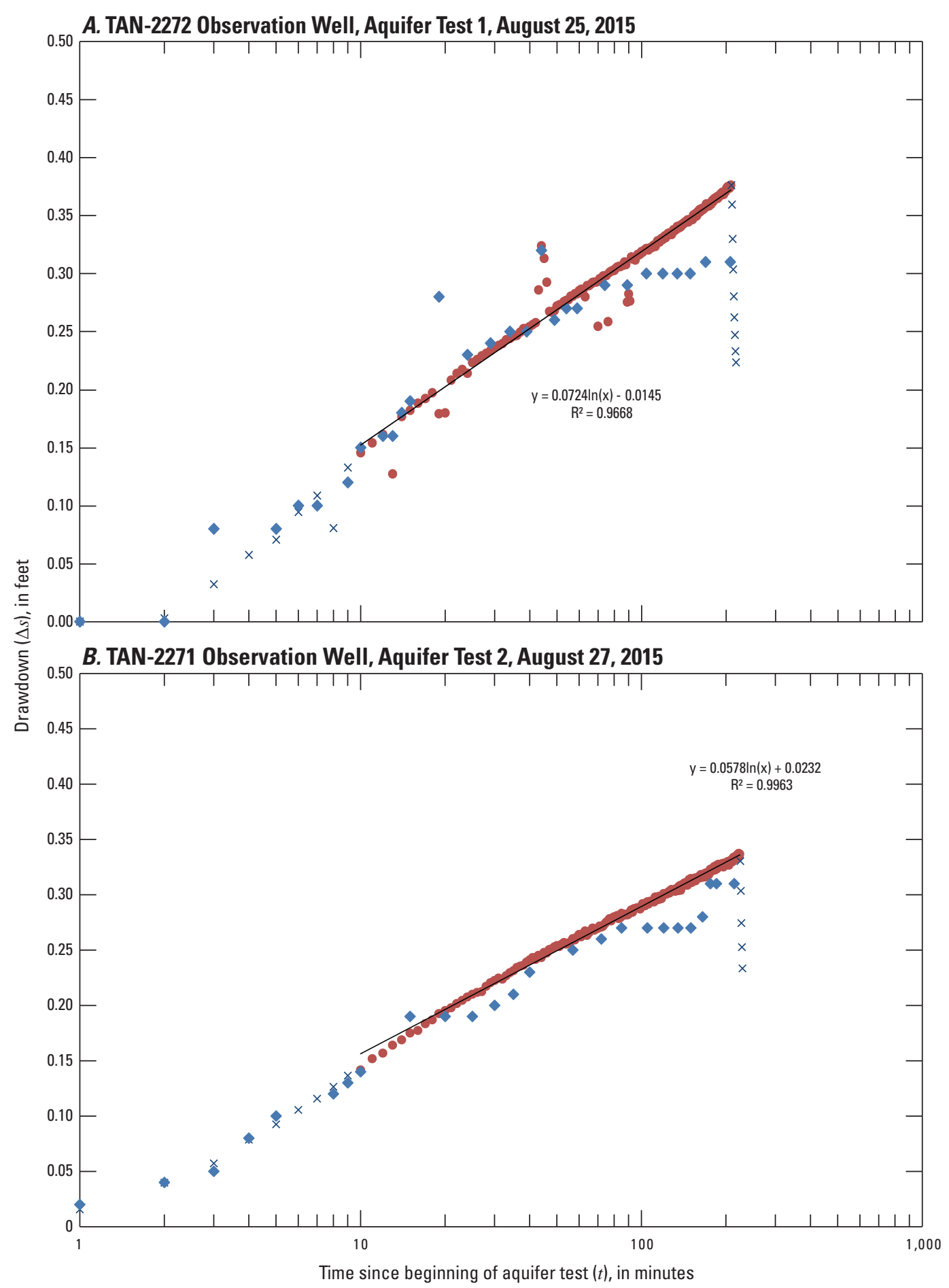

EXPLANATION

Log (data used)

- Data used

$\times \quad$ Data ignored

- Etape \#4

Figure 16. Aquifer test 1 and 2 observation well time series for wells $(A)$ TAN-2271 and (B) TAN-2272, Test Area North, Idaho National Laboratory, Idaho. 
The transmissivity and conductivity for the aquifer test 2 (TAN-2272) $\mathrm{T}_{2 \mathrm{p}}$ and $\mathrm{K}_{2 \mathrm{p}}$ were estimated at $8.1 \times 10^{3} \mathrm{ft}^{2} / \mathrm{d}$ and $11.5 \mathrm{ft} / \mathrm{d}$. The observation well data (TAN-2271), $\mathrm{T}_{20}$ and $\mathrm{K}_{20}$ were estimated at $7.8 \times 10^{3} \mathrm{ft}^{2} / \mathrm{d}$ and $11.1 \mathrm{ft} / \mathrm{d}$. Calculations of these parameters using a combination of equations 1 and 3 are:

$$
\begin{aligned}
& T_{2 p}=\frac{2.3 Q_{2}}{4 \pi} \frac{1}{\Delta s_{2}}=\frac{2.3 \times 3.98 \mathrm{ft}^{3} / \mathrm{min}}{4 \pi \times 0.130 \mathrm{ft}} \\
& =5.6 \mathrm{ft}^{2} / \mathrm{min} \text { or } 8.1 \times 10^{3} \mathrm{ft}^{2} / \mathrm{d} \\
& K_{2 p}=\frac{T_{2}}{b}=\frac{5.6 \mathrm{ft}^{2} / \mathrm{min}}{700 \mathrm{ft}} \\
& =8.0 \times 10^{-3} \mathrm{ft} / \mathrm{min} \text { or } 11.5 \mathrm{ft} / \mathrm{d} \\
& T_{2 o}=\frac{2.3 Q_{2}}{4 \pi} \frac{1}{\Delta s_{2}}=\frac{2.3 \times 3.98 \mathrm{ft}^{3} / \mathrm{min}}{4 \pi \times 0.133 \mathrm{ft}} \\
& =5.4 \mathrm{ft}^{2} / \mathrm{min} \text { or } 7.8 \times 10^{3} \mathrm{ft}^{2} / \mathrm{d} \\
& \begin{aligned}
K_{2 p} & =\frac{T_{2}}{b}=\frac{5.4 \mathrm{ft}^{2} / \mathrm{min}}{700 \mathrm{ft}} \\
& =7.8 \times 10^{-3} \mathrm{ft} / \mathrm{min} \text { or } 11.1 \mathrm{ft} / \mathrm{d} .
\end{aligned}
\end{aligned}
$$

The estimated hydraulic properties from the aquifer tests 1 and 2 suggest TAN-2271 and TAN-2272 are hydraulically similar. Drawdown measured for the aquifer test 1 (TAN-2271) averaged $1.96 \mathrm{ft}$ in the pumping well and $0.31 \mathrm{ft}$ in the observation well; whereas, drawdown measured for the aquifer test 2 (TAN-2272) averaged $1.14 \mathrm{ft}$ in the pumping well and $0.29 \mathrm{ft}$ in the observation well. Based on observation well data collected during both aquifer tests and geophysical log data, fracture networks between the well pair are well connected at a distance of about $63 \mathrm{ft}$. Differences in hydraulic property estimates could be attributed to slightly higher fracture density in TAN-2272 reported near the bottom of the well.

A comparison between the estimated TAN-2271 and TAN-2272 transmissivity and values determined from past aquifer tests conducted at wells within the vicinity of TAN show good agreement (fig. 2, table 4). The estimated transmissivity values from these past aquifer tests (Ackerman, 1991) ranged from $3.0 \times 10^{1}$ to $5.0 \times 10^{5} \mathrm{ft}^{2} / \mathrm{d}$. The average TAN-2271 and TAN-2272 hydraulic conductivity values were well within the range of values reported both in the literature for similar rock types as Domenico and Schwartz, (1990) and Freeze and Cherry (1979) report a range of hydraulic conductivity values for permeable basalt from $5.7 \times 10^{-2}$ to $5.7 \times 10^{3} \mathrm{ft} / \mathrm{d}$; and the hydraulic conductivity of the ESRP aquifer at or near the INL ranges from about $1.0 \times 10^{-2}$ to $3.2 \times 10^{4} \mathrm{ft} / \mathrm{d}$.(Anderson and others, 1999).

Table 4. Comparison of transmissivity values estimated from aquifer tests at wells near wells TAN-2271 and TAN-2272, near Test Area North, Idaho National Laboratory, Idaho.

[Locations of wells are shown in figure 2. Local name: Local well identifier used in this study. Site identifier: Unique numerical identifiers used to access well data (http://waterdata.usgs.gov/nwis). L ongitude and L atitude: Referenced to NAD 27 (North American Datum of 1927). Distance to wells: Straight line distance within the aerial dimension to wells TAN-2271 and TAN-2272. Abbreviations: $\mathrm{ft}^{2} / \mathrm{d}$, foot squared per day; mi, mile]

\begin{tabular}{lccccc}
\hline \multicolumn{1}{c}{ Local name } & Site identifier & Longitude & Latitude & $\begin{array}{c}\text { Transmissivity } \\
\left(\mathbf{f t}^{2} / \mathbf{d}\right)\end{array}$ & $\begin{array}{c}\text { Distance } \\
\text { to wells } \\
(\mathbf{m i})\end{array}$ \\
\hline ANP 3 & 435053112423201 & $112^{\circ} 42^{\prime} 31.4^{\prime \prime}$ & $43^{\circ} 50^{\prime} 52.5^{\prime \prime}$ & $3.0 \times 10^{1}$ & 0.3 \\
ANP 6 & 435152112443101 & $112^{\circ} 44^{\prime} 31.4^{\prime \prime}$ & $43^{\circ} 51^{\prime} 51.6^{\prime \prime}$ & $5.0 \times 10^{5}$ & 1.9 \\
TAN 1 & 435056112420001 & $112^{\circ} 42^{\prime} 00.0^{\prime \prime}$ & $43^{\circ} 50^{\prime} 56.0^{\prime \prime}$ & $2.9 \times 10^{4}$ & 0.5 \\
TAN 2 & 435100112420701 & $112^{\circ} 42^{\prime} 07.0^{\prime \prime}$ & $43^{\circ} 51^{\prime} 00.0^{\prime \prime}$ & $1.6 \times 10^{4}$ & 0.4 \\
USGS 24 & 435053112420801 & $112^{\circ} 42^{\prime} 12.3^{\prime \prime}$ & $43^{\circ} 50^{\prime} 50.8^{\prime \prime}$ & $1.4 \times 10^{4}$ & 0.3 \\
\hline
\end{tabular}




\section{Water-Sample Collection}

\section{Sample Collection Methods}

Water-sample collection at wells TAN-2271 and TAN-2272 generally followed guidelines documented in the USGS National Field Manual for the Collection of Water-Quality Data (U.S. Geological Survey, variously dated) and in Bartholomay and others (2014); water-quality samples were collected at the end of aquifer testing in wells TAN-2271 and TAN-2272, after the wells were purged for about 3 hours. Water-quality samples were collected from TAN-2271 and TAN-2272 on August 25 and August 27, 2015, respectively. Water samples were collected from a 0.25 -in. diameter SS sample port installed off of piping at the wellhead after the well was purged with a submersible pump and field measurements were stable. The constituents sampled after well completion were selected to provide a characterization of baseline water chemistry and radionuclide concentrations. Field measurements of water temperature, $\mathrm{pH}$, specific conductance, dissolved oxygen, and alkalinity were collected for both wells (table 5).

Table 5. Concentrations of selected chemical and radiochemical constituents in water from wells TAN-2271 and TAN-2272, Test Area North, Idaho National Laboratory, Idaho.

[Locations of wells are shown in figures 1 and 2. Analytical results in micrograms per liter unless otherwise noted. Samples were analyzed at the USGS National Water Quality Laboratory in Lakewood, Colo., unless otherwise indicated. C onstituent or measurement: (mm-dd-yy) indicates month-day-year. RSIL, USGS Reston Stable Isotope Laboratory in Reston, Va.; RESL, Radiological and Environmental Sciences Laboratory; Uncertainty of radiochemical constituents is 1 sample standard deviation (1s). Uncertainty of deuterium and oxygen-18 is \pm 1.5 per mil. Concentrations that meet or exceed the reporting level of 3 times the $1 \mathrm{~s}$ value are shown in boldface type. A bbreviations: $\mathrm{CaCO}_{3}$, calcium carbonate; ${ }^{\circ} \mathrm{C}$, degrees Celsius; $\mathrm{N}$, nitrogen; $\mathrm{P}$, phosphorus; $\mathrm{pCi} / \mathrm{L}$, picocuries per liter; per mil, part per thousand difference relative to a standard; $\mu \mathrm{S} / \mathrm{cm}$, microsiemens per centimeter at 25 degrees Celsius; mg/L, milligram per liter; <, less than; \pm , plus or minus]

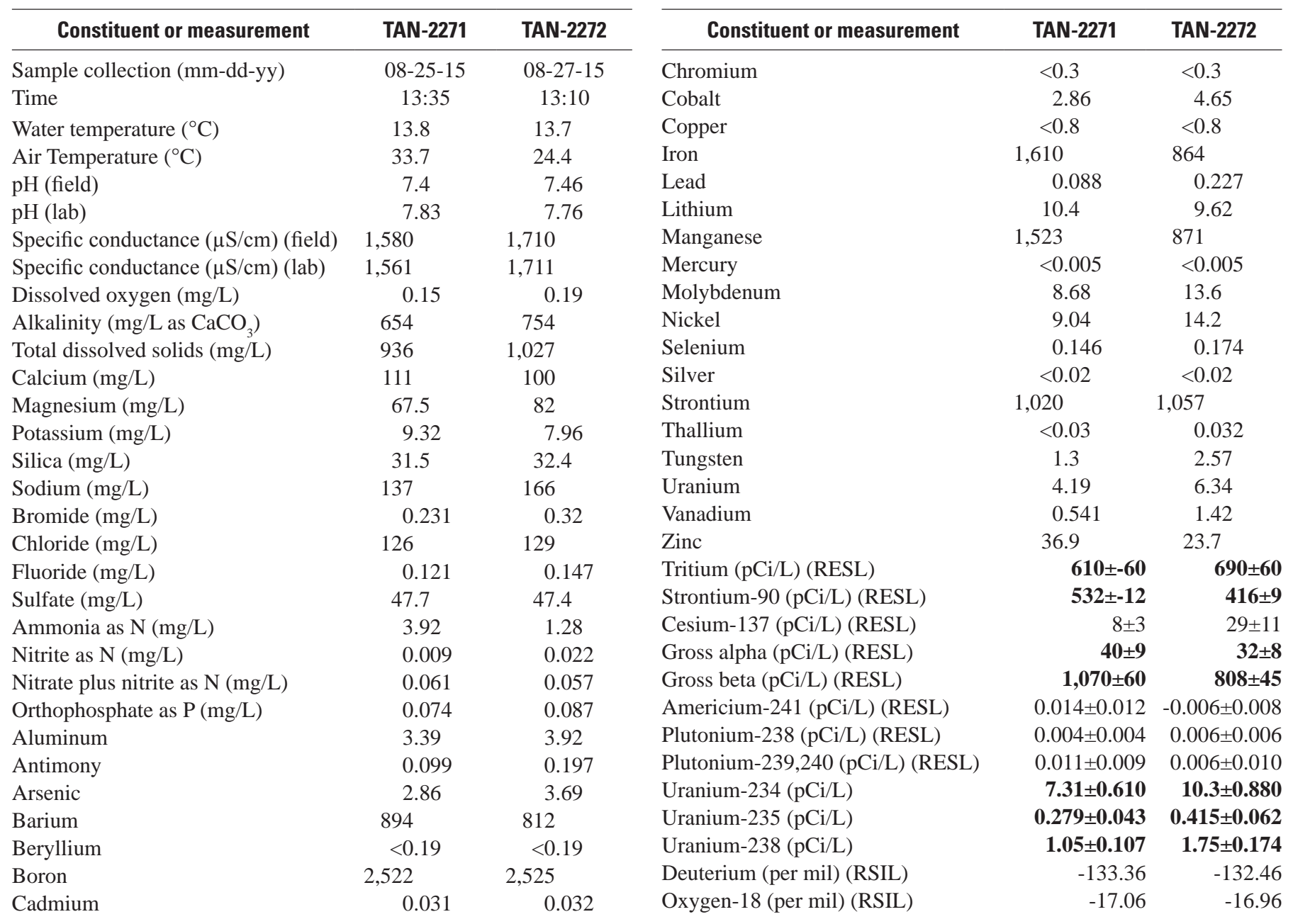


Table 5. Concentrations of selected chemical and radiochemical constituents in water from wells TAN-2271 and TAN-2272, Test Area North, Idaho National Laboratory, Idaho.-Continued

\begin{tabular}{|c|c|c|c|c|c|}
\hline Constituent or measurement & TAN-2271 & TAN-2272 & Constituent or measurement & TAN-2271 & TAN-2272 \\
\hline Acrylonitrile & $<2.5$ & $<2.5$ & Toluene & 0.252 & 2.23 \\
\hline Bromobenzene & $<0.2$ & $<0.2$ & trans-1,3-dichloropropene & $<0.2$ & $<0.2$ \\
\hline Bromochloromethane & $<0.2$ & $<0.2$ & Tribromomethane & $<0.2$ & $<0.2$ \\
\hline Bromomethane & $<0.4$ & $<0.4$ & Trichloroethene & 12 & 33 \\
\hline CFC-12 & $<0.2$ & $<0.2$ & Vinyl chloride & 0.493 & 2.85 \\
\hline CFC-113 & $<0.1$ & $<0.1$ & Xylene & $<0.2$ & $<0.2$ \\
\hline $\mathrm{CHBrC} 12$ & $<0.1$ & $<0.1$ & 1,1,1-trichloroethane & $<0.1$ & $<0.1$ \\
\hline Chlorobenzene & $<0.1$ & $<0.1$ & 1,1,1,2-tetrachloroethane & $<0.2$ & $<0.2$ \\
\hline Chloroethane & $<0.2$ & $<0.2$ & 1,1,2,2-tetrachloroethane & $<0.2$ & $<0.2$ \\
\hline Chloromethane & $<0.2$ & $<0.2$ & 1,1,2-trichloroethane & $<0.2$ & $<0.2$ \\
\hline Dibromochloromethane & $<0.2$ & $<0.2$ & 1,2,3-trichloropropane & $<0.2$ & $<0.2$ \\
\hline Dibromomethane & $<0.2$ & $<0.2$ & 1,2,3-trichlorobenzene & $<0.2$ & $<0.2$ \\
\hline Dichloromethane & $<0.2$ & $<0.2$ & 1,2,4-trichlorobenzene & $<0.2$ & $<0.2$ \\
\hline Ethylbenzene & $<0.1$ & $<0.1$ & 1,2,4-trimethylbenzene & $<0.2$ & $<0.2$ \\
\hline Hexachlorobutadiene & $<0.2$ & $<0.2$ & 1,2-dibromoethane & $<0.2$ & $<0.2$ \\
\hline Isopropylbenzene & $<0.2$ & $<0.2$ & 1,2-dichlorobenzene & $<0.1$ & $<0.1$ \\
\hline MTBE & $<0.2$ & $<0.2$ & 1,2-dichloroethane & $<0.2$ & $<0.2$ \\
\hline Naphthalene & $<0.5$ & $<0.5$ & 1,2-dichloropropane & $<0.1$ & $<0.1$ \\
\hline n-butylbenzene & $<0.2$ & $<0.2$ & 1,3-dichlorobenzene & $<0.1$ & $<0.1$ \\
\hline n-propylbenzene & $<0.2$ & $<0.2$ & 1,3-dichloropropane & $<0.2$ & $<0.2$ \\
\hline sec-butylbenzene & $<0.2$ & $<0.2$ & 1,3,5-trimethylbenzene & $<0.2$ & $<0.2$ \\
\hline Styrene & $<0.1$ & $<0.1$ & 1,4-dichlorobenzene & $<0.1$ & $<0.1$ \\
\hline
\end{tabular}

Samples were processed in the field according to protocols for the constituents. Samples to be analyzed for chemical constituents by the USGS National Water Quality Laboratory (NWQL) were placed in containers and preserved in accordance with laboratory requirements specified by Bartholomay and others (2014, appendix A). Containers and preservatives were supplied by the NWQL and had gone through a rigorous quality-control procedure (Pritt, 1989, p. 75) to minimize sample contamination. Samples requiring field filtration were filtered through a disposable $0.45-\mu \mathrm{m}$ cartridge that had been pre-rinsed with at least $2 \mathrm{~L}$ of deionized water. Samples to be analyzed for radionuclides by the Radiological and Environmental Sciences Laboratory (RESL) at the INL were placed in containers and preserved in accordance with laboratory requirements specified by Bodnar and Percival (1982) and Bartholomay and others (2014, appendix A). Samples for the stable isotopes of oxygen and hydrogen were collected in bottles provided by NWQL and shipped to the USGS Reston Stable Isotope Laboratory (RSIL)-Isotope Fractionation Project in Reston, Virginia, for analysis.

\section{Analytical Methods}

Analytical methods used by the USGS for selected organic, inorganic, and radionuclide constituents are described by Goerlitz and Brown (1972), Thatcher and others (1977), Wershaw and others (1987), Fishman and Friedman (1989), Faires (1993), Fishman (1993), Rose and Schroeder (1995), and McCurdy and others (2008). Analytical methods used for selected isotopic constituents were summarized by Busenberg and others (2000). A discussion of procedures and methods used by the RESL for the analysis of radionuclides in water is provided by Bodnar and Percival (1982), Sill and Sill (1994), and the U.S. Department of Energy (1995). 


\section{Guidelines for Interpretation of Analytical Results}

Concentrations of radionuclides are reported with an estimated sample standard deviation, $\boldsymbol{s}$, which is obtained by propagating sources of analytical uncertainty in measurements. McCurdy and others (2008) provided details on interpreting radiological data used by the USGS. The guidelines for interpreting analytical results are based on an extension of a method proposed by Currie (1984) that is given in Davis and others (2013). In this report, radionuclide concentrations less than $3 s$ are considered to be less than the "reporting level.” The reporting level should not be confused with the analytical method detection limit, which is based on laboratory procedures.

Concentrations of inorganic and organic constituents are reported with reference to reporting limits determined using detection and quantitation calculation (DQCALC) software and are reported as detection limits from DQCALC (DLDQC) for inorganic constituents and minimum reporting levels (MRL) for organic constituents. The MRL is the smallest measured constituent concentration that can be reliably reported using a specific analytical method (Timme, 1995). The DLDQC is one of four new report level codes adopted by the NWQL to replace the long-term method detection limit (U.S. Geological Survey, 2015). DLDQC is described as the lowest concentration that with 90 percent confidence will be exceeded no more than 1 percent of the time when a blank sample is measured $(\leq 1$ percent false positive risk; U.S. Geological Survey, 2015, p. 11). DQCALC is a Microsoft Excel ${ }^{\circledR}$-based software package used to compute a method detection estimate (Standard Practice D7510-10; American Society for Testing and Materials International, 2010). See U.S. Geological Survey (2105) for a more detailed explanation of the DQCALC procedures. Childress and others (1999) provide details about the approach used by the USGS regarding detection levels and reporting levels. For most of the constituents in this report, reported concentrations generally are greater than the DLDQCs or MRLs, but some are given as less than.

As a matter of convention, concentrations of stable isotopes are reported as relative isotopic ratios (Toran, 1982). Busenberg and others (2000) described stable isotope data in more detail.

\section{Inorganic Chemistry Data}

Water samples collected from TAN-2271 and TAN-2272 were sent to the NWQL to be analyzed for dissolved concentrations of (1) cations of calcium, magnesium, potassium, silica, and sodium; (2) anions of bromide, chloride, fluoride, and sulfate; and (3) trace elements of aluminum, antimony, arsenic, barium, beryllium, boron, cadmium, chromium, cobalt, copper, iron, lead, lithium, manganese, mercury, molybdenum, nickel, selenium, silver, strontium, thallium, tungsten, uranium, vanadium, and zinc. Additionally, samples were collected and sent to the NWQL to be analyzed for dissolved concentrations of ammonia as nitrogen $(\mathrm{N})$, nitrite as $\mathrm{N}$, nitrate plus nitrite as $\mathrm{N}$, and orthophosphate as phosphorus (P) (table 5).

A comparison of the data for the samples collected from wells TAN-2271 and TAN-2272 indicates very similar chemistry of the aquifer water at both wells (table 5). For example, calcium concentrations were 111 and $100 \mathrm{mg} / \mathrm{L}$, potassium concentrations were 9.32 and $7.96 \mathrm{mg} / \mathrm{L}$, silica concentrations were 31.5 and $32.4 \mathrm{mg} / \mathrm{L}$, chloride concentrations were 126 and $129 \mathrm{mg} / \mathrm{L}$, fluoride concentrations were 0.121 and 0.147 , and sulfate concentrations were 47.7 and $47.4 \mathrm{mg} / \mathrm{L}$, respectively for TAN-2271 and TAN-2272. Ammonia concentrations were much higher and nitrate plus nitrite as $\mathrm{N}$ concentrations were much lower than other water in the ESRP aquifer at the INL (Davis and others, 2013). The nutrient concentrations are probably being affected by the amendment put into the aquifer at this location to help decrease trichloroethene concentrations as part of the Idaho Cleanup Project.

\section{Organic Chemistry Data}

Water samples collected from wells TAN-2271 and TAN-2272 in August 2015 were analyzed at the NWQL for volatile organic compounds (VOCs). Most of the VOCs had concentrations less than their laboratory MRL. Exceptions for wells TAN 2271 and 2272, respectively, include cis-1,2-dichloroethene (3.37 and $14.2 \mu \mathrm{g} / \mathrm{L}$ ); toluene (0.252 and $2.23 \mu \mathrm{g} / \mathrm{L})$; trans-1,2-dichloroethene (22.7 and $27.2 \mu \mathrm{g} / \mathrm{L})$; trichloroethene (12 and $33 \mu \mathrm{g} / \mathrm{L})$; vinyl chloride (0.493 and $2.85 \mu \mathrm{g} / \mathrm{L}) ; 1$,1-dichloroethane (0.177 and $0.196 \mu \mathrm{g} / \mathrm{L})$; and tetrachloroethene $(0.131 \mu \mathrm{g} / \mathrm{L}$ in well TAN 2271). Concentrations of trichloroethene exceeded the Environmental Protection Agency's (EPA) maximum contaminant level (MCL) for drinking water of $5 \mu \mathrm{g} / \mathrm{L}$ (U.S. Environmental Protection Agency, 2014) in both wells. Vinyl chloride exceeded its MCL of $2 \mu \mathrm{g} / \mathrm{L}$ in well TAN 2272.

\section{Stable Isotope Data}

Water samples collected from wells TAN-2271 and TAN2272 in August 25 and 27, 2015, respectively, were analyzed at the RSIL for relative concentrations of the stable isotopes of deuterium $\left({ }^{2} \mathrm{H}\right)$ and oxygen-18 $\left({ }^{18} \mathrm{O}\right)$. Because the absolute measurement of isotopic ratios is analytically difficult, relative isotopic ratios were measured instead (Toran, 1982) and are expressed in delta notation as part per mil (part per thousand difference). For example, ${ }^{18} \mathrm{O} /{ }^{16} \mathrm{O}$ of a sample is compared with ${ }^{18} \mathrm{O} /{ }^{16} \mathrm{O}$ of a standard: 


$$
\delta{ }^{18} \mathrm{O}=\left(\mathrm{R}_{\text {sample }} / \mathrm{R}_{\text {standard }}-1\right) \times 1,000
$$

where

$$
\begin{aligned}
& R_{\text {sample }} \text { is the }{ }^{18} \mathrm{O} /{ }^{16} \mathrm{O} \text { ratio in the sample, } \\
& \mathrm{R}_{\text {standard }} \text { is the }{ }^{18} \mathrm{O} /{ }^{16} \mathrm{O} \text { ratio in the standard, and } \\
& \text { Delta }{ }^{18} \mathrm{O} \text { is the relative concentration, in units of parts } \\
& \text { per thousand. }
\end{aligned}
$$

Delta ${ }^{18} \mathrm{O}$ is referred to as delta notation; it is the value reported by isotopic laboratories for stable isotope analysis. ${ }^{2} \mathrm{H} /{ }^{1} \mathrm{H}$ is defined in a similar manner with the respective ratios replacing ${ }^{18} \mathrm{O} /{ }^{16} \mathrm{O}$ in $\mathrm{R}_{\text {sample }}$ and $\mathrm{R}_{\text {standard }}$. The standard used for determining Delta ${ }^{18} \mathrm{O}$ and Delta ${ }^{2} \mathrm{H}$ in water is standard mean ocean water as defined by Craig (1961).

Stable isotope concentration data for deuterium and oxygen-18 samples collected from TAN-2271 and TAN2272 were -133.36 and -17.06 , and -132.46 and -16.96 per mil for each well, respectively. Concentrations of deuterium and oxygen-18 isotopes were most similar to stable isotopes in Mud Lake surface water (Ott and others, 1994, table 4) as compared to Birch Creek surface water and concentrations in other wells in the northern part of the INL (figs. 1 and 2).

\section{Radiochemical Data}

Water samples collected from TAN-2271 and TAN-2272 in August 2015 were analyzed at the RESL for tritium; strontium-90; gross alpha, beta, and gamma radioactivity; plutonium-238, and plutonium-239, -240 (undivided); and americium-241. Additionally, samples were collected for uranium isotopes and analyzed by a USGS NWQL contract laboratory (table 5). Concentrations of all the radionuclides analyzed were greater than the reporting level except for cesium-137 and the plutonium and americium isotopes (table 5). Strontium-90 concentrations were $532 \pm 12$ and $416 \pm 9$ picocuries per liter (pCi/L) for wells TAN-2271 and TAN-2272, respectively, and were much greater than the EPA's MCL for drinking water of 8 pCi/L (U.S. Environmental Protection Agency, 2014).

\section{Summary}

In 2015, the U.S. Geological Survey, in cooperation with the U.S. Department of Energy, drilled and constructed boreholes TAN-2271 and TAN-2272 for stratigraphic framework analyses and long-term groundwater monitoring of the eastern Snake River Plain aquifer at the Idaho National Laboratory. Borehole TAN-2271 initially was cored to collect continuous geologic data and then re-drilled to complete construction as a monitoring well. Borehole TAN-2272 was drilled and partially cored from 210 to $284 \mathrm{ft} \mathrm{BLS}$ and constructed as a monitoring well. Boreholes TAN-2271 and TAN-2272 are separated by about 63 feet (ft) and have similar stratigraphic layers and hydrologic characteristics, determined from collected geophysical and aquifer test data. The final construction for boreholes TAN-2271 and TAN-2272 required 10-inch (in.) diameter carbon-steel well casing, dual stainless steel vapor lines, and 9.9-in. diameter open-hole construction; the open-hole interval was completed about 55-60 ft into the eastern Snake River Plain aquifer. Following construction and data collection, submersible pumps and water-level access lines were placed to allow for aquifer testing, for collecting periodic water samples, and for measuring water levels.

Geophysical and borehole video logs were collected at various times during the drilling and construction process at boreholes TAN-2271 and TAN-2272. Geophysical logs were examined in conjunction with the core material for borehole TAN-2271; additionally, geophysical data were examined from borehole TAN-2272 to confirm geologic and hydrologic similarities between boreholes TAN-2271 and TAN-2272. Geophysical data suggest the occurrence of fractured and (or) vesiculated basalt, dense basalt, and limited sediment layering in both the saturated and unsaturated zones. Gyroscopic deviation measurements were used to measure horizontal and vertical deviation in boreholes TAN-2271 and TAN-2272.

Single-well aquifer tests were conducted following construction at wells TAN-2271 and TAN-2272 and data were used to provide estimates of transmissivity and hydraulic conductivity. The transmissivity and hydraulic conductivity for well TAN-2271 were estimated at $4.1 \times 10^{3}$ square feet per day ( $\left.\mathrm{ft}^{2} / \mathrm{d}\right)$, and 5.8 feet per day (ft/d), respectively. The transmissivity and hydraulic conductivity for TAN-2272 were estimated at $8.1 \times 10^{3} \mathrm{ft}^{2} / \mathrm{d}$, and $11.5 \mathrm{ft} / \mathrm{d}$, respectively. Measured flow rates remained relatively constant in wells TAN-2271 and TAN-2272, with average pumping rates of 29.6 and 29.8 gallons per minute during the aquifer test 1 and 2 , respectively. The transmissivity for wells TAN-2271 and TAN-2272 were within the range of expected values $\left(3.0 \times 10^{1}\right.$ to $5.0 \times 10^{5} \mathrm{ft}^{2} / \mathrm{d}$ ) determined from previous aquifer tests conducted in other wells near Test Area North.

Water samples were analyzed for cations, anions, metals, nutrients, total organic carbon, volatile organic compounds, stable isotopes, and radionuclides. Water samples for most of the inorganic constituents showed similar water chemistry in both wells. Water samples for strontium-90, trichlorethene, and vinyl chloride exceeded maximum contaminant levels (MCLs) for public drinking water supplies in well TAN-2272 and strontium-90 and trichloroethene exceeded MCLs in well TAN-2271. 


\section{References Cited}

Ackerman, D.J., 1991, Transmissivity of the Snake River Plain aquifer at the Idaho National Engineering Laboratory, Idaho: U.S. Geological Survey Water-Resources Investigations Report 91-4058 (DOE/ID-22097), 35 p. [Also available at http://pubs.er.usgs.gov/publication/ wri914058.]

Ackerman, D.J., Rattray, G.W., Rousseau, J.P., Davis, L.C., and Orr, B.R., 2006, A conceptual model of ground-water flow in the eastern Snake River Plain aquifer at the Idaho National Laboratory and vicinity with implications for contaminant transport: U.S. Geological Survey Scientific Investigations Report 2006-5122, 62 p. [Also available at http://pubs.usgs.gov/sir/2006/5122/.]

Ackerman, D.J., Rousseau, J.P., Rattray, G.W., and Fisher, J.C., 2010, Steady-state and transient models of groundwater flow and advective transport, Eastern Snake River Plain aquifer, Idaho National Laboratory and vicinity, Idaho: U.S. Geological Survey Scientific Investigations Report 2010-5123, 220 p.

Anderson, S.R., Kuntz, M.A., and Davis, L.C., 1999, Geologic controls of hydraulic conductivity in the Snake River Plain aquifer at and near the Idaho National Engineering and Environmental Laboratory, Idaho: U.S. Geological Survey Water-Resources Investigations Report 99-4033 (DOE/ ID-22155), 38 p. [Also available at http://pubs.er.usgs.gov/ publication/wri994033.]

Anderson, S.R., and Liszewski, M.J., 1997, Stratigraphy of the unsaturated zone and the Snake River Plain aquifer at and near the Idaho National Engineering Laboratory, Idaho: U.S. Geological Survey Water-Resources Investigations Report 97-4183 (DOE/ID-22142), 65 p. [Also available at http://pubs.er.usgs.gov/publication/wri974183.]

American Society for Testing and Materials International (ASTM) International, 2010, Standard practice for performing detection and quantitation estimation and data assessment utilizing DQCALC software, based on ASTM practices D6091 and 20 D6512 of Committee D19 on water: ASTM D7510-10, 2 p. [Also available at http://www.astm. org/Standards/D7510.htm.]

Bartholomay, R.C., Maimer, N.V., and Wehnke, A.J., 2014, Field methods and quality-assurance plan for water-quality activities and water-level measurements, U.S. Geological Survey, Idaho National Laboratory, Idaho: U.S. Geological Survey Open-File Report 2014-1146 (DOE/ID-22230), $66 \mathrm{p}$.
Bartholomay, R.C., Tucker, B.J., Ackerman, D.J., and Liszewski, M.J., 1997, Hydrologic conditions and distribution of selected radiochemical and chemical constituents in water, Snake River Plain aquifer, Idaho National Engineering Laboratory, Idaho, 1992 through 1995: U.S. Geological Survey Water-Resources Investigations Report 97-4086 (DOE/ID-22137), 57 p. [Also available at http://pubs.er.usgs.gov/publication/ wri974086.]

Bartholomay, R.C., and Twining, B.V., 2015, Hydrologic influences on water-level changes in the eastern Snake River Plain aquifer and near the Idaho National Laboratory, Idaho, 1949-2014: U.S. Geological Survey Scientific Investigations Report 2015-5085 (DOE/ID-22236), 36 p., http://dx.doi.org/10.3133/sir20155085.

Blackwell, D.D., Kelley, S., and Steele, J.L., 1992, Heat flow modeling of the Snake River Plain, Idaho: Idaho National Engineering Laboratory, Department of Energy contractor report no. EGG-NPR-10790, 109 p.

Bodnar, L.Z., and Percival, D.R., eds., 1982, RESL Analytical Chemistry Branch procedures manual: U.S. Department of Energy Report IDO-12096, 364 p.

Braile, L.W., Smith, R.B., Ansorge, Jörg, Baker, M.R., Sparlin, M.A., Prodehl, Claus, Schilly, M.M., Healy, J.H., Mueller, St., and Olsen, K.H., 1982, The Yellowstone-Snake River Plain seismic profiling experiment-Crustal structure of the Eastern Snake River Plain: Journal of Geophysical Research, v. 87, no. B4, p. 2,597-2,609.

Busenberg, Eurybiades, Plummer, L.N., and Bartholomay, R.C., 2001, Estimated age and source of the young fraction of ground water at the Idaho National Engineering and Environmental Laboratory: U.S. Geological Survey Water-Resources Investigations Report 2001-4265 (DOE/ ID-22177), $144 \mathrm{p}$.

Busenberg, Eurybiades, Plummer, L.N., Doughten, M.W., Widman, P.K., and Bartholomay, R.C., 2000, Chemical and isotopic composition and gas concentrations of ground water and surface water from selected sites at and near the Idaho National Engineering and Environmental Laboratory, Idaho, 1994-97: U.S. Geological Survey Open-File Report 2000-81 (DOE/ ID-22164), 51 p. [Also available at http:// pubs.er.usgs.gov/publication/ofr0081.]

Cecil, L.D., Welhan, J.A., Green, J.R., Frape, S.K., and Sudicky, E.R., 2000, Use of chlorine-36 to determine regional-scale aquifer dispersivity, eastern Snake River Plain aquifer, Idaho/USA, in Nuclear instruments and methods in physics research section B-Beam interactions with materials and atoms: Vienna, Austria, International Conference on Accelerator Mass Spectrometry, 8th, 1999, v. 172, p. 679-687. 
Childress, C.J.O., Foreman, W.T., Conner, B.F., and Maloney, T.J., 1999, New reporting procedures based on long-term method detection levels and some considerations for interpretations of water-quality data provided by the U.S. Geological Survey National Water Quality Laboratory: U.S. Geological Survey Open-File Report 99-193, 19 p. [Also available at http://water.usgs.gov/owq/OFR_99-193/.]

Christensen Products, 1997, C wireline system: Christensen Products Web page, accessed May 2008, at http:// christensenproducts.com.

Cooper, H.H., and Jacob, C.E., 1946, A generalized graphical method for evaluating formation constants and summarizing well field history: American Geophysical Union Transactions, v. 27, p. 526-534.

Craig, Harmon, 1961, Isotopic variation in meteoric water: Science, v. 133, p. 1,702-1,703.

Currie, L.A., 1984, Lower limit of detection-Definition and elaboration of a proposed position for radiological effluent and environmental measurements: U.S. Nuclear Regulatory Commission NUREG/CR-4007, 139 p.

Davis, L.C., Bartholomay, R.C., and Rattray, G.W., 2013, An update of hydrologic conditions and distribution of selected constituents in water, eastern Snake River Plain aquifer and perched groundwater zones, Idaho National Laboratory, Idaho, emphasis 2009-11: U.S. Geological Survey Scientific Investigations Report 2013-5214, (DOE/ ID-22226), 90 p. [Also available at http://pubs.er.usgs.gov/ publication/sir20135214.]

Davis. L.C., Hannula, S.R., and Bowers, Beverly, 1997, Procedures for use of, and drill cores and cuttings available for study at the Lithologic Core Storage Library, Idaho National Engineering Laboratory, Idaho: U.S. Geological Survey Open-File Report 97-124 (DOE/ID-22135), 31 p. [Also available at http://pubs.er.usgs.gov/publication/ ofr97124.]

Domenico, P.A., and Schwartz, F.W., 1990, Physical and Chemical Hydrogeology: New York, John Wiley \& Sons, Inc., 824 p.

Duke, C.L., Roback, R.C., Reimus, P.W., Bowman, R.S., McLing, T.L., Baker, K.E., and Hull, L.C., 2007, Elucidation of flow and transport processes in a variably saturated system of interlayered sediment and fractured rock using tracer tests: Vadose Zone Journal, v. 6, no. 4, p. 855-867.

Faires, L.M., 1993, Methods of analysis by the U.S. Geological Survey National Water Quality LaboratoryDetermination of metals in water by inductively coupled plasma-mass spectrometry: U.S. Geological Survey OpenFile Report 92-634, 28 p. [Also available at http://pubs. er.usgs.gov/publication/ofr92634.]
Fishman, M.J., ed., 1993, Methods of analysis by the U.S. Geological Survey National Water Quality LaboratoryDetermination of inorganic and organic constituents in water and fluvial sediments: U.S. Geological Survey OpenFile Report 93-125, 217 p. [Also available at http://pubs. er.usgs.gov/publication/ofr93125.]

Fishman, M.J., and Friedman, L.C., eds., 1989, Methods for determination of inorganic substances in water and sediments: U.S. Geological Survey Techniques of WaterResources Investigations, book 5, chap. A1, 545 p. [Also available at http://pubs.usgs.gov/twri/twri5-a1/.]

Freeze, R.A., and Cherry, J.A., 1979, Groundwater: Englewood Cliffs, N.J., Prentice Hall, Inc., 604 p.

Garabedian, S.P., 1986, Application of a parameter-estimation technique to modeling the regional aquifer underlying the eastern Snake River Plain, Idaho: U.S. Geological Survey Water-Supply Paper 2278, 60 p. [Also available at http:// pubs.er.usgs.gov/publication/wsp2278.]

Goerlitz, D.F., and Brown, Eugene, 1972, Methods for analysis of organic substances in water: U.S. Geological Survey Techniques of Water-Resources Investigations, book 5, chap. A3, 40 p.

Halford, K.J., Weight, W.D., and Schreiber, R.P., 2006, Interpretation of transmissivity estimates from single-well pumping aquifer tests: Ground Water, v. 44, no. 3, p. 467-471.

Izbicki, J.A., Clar, D.A., Pimentel, M.I., Land, M.T., Radyk, J., and Michel, R.L., 2000, Data from a thick unsaturatedzone underlying Oro Grande and Sheep Creek washes in the western part of the Mojave Desert, near Victorville, San Bernardino County, California: U.S. Geological Survey Open-File Report 00-262, 133 p.

Keys, W.S., 1990, Borehole geophysics applied to groundwater investigations: U.S. Geological Survey Techniques of Water-Resources Investigations, book 2, chap. E2, 150 p.

Lane, J.W., Jr., Williams, J.H., Johnson, C.D., Savino, D.M., Sr., and Haeni, F.P., 2002, An integrated geophysical and hydraulic investigation to characterize a fractured-rock aquifer, Norwalk, Connecticut: U.S. Geological Survey Water-Resources Investigations Report 2001-4133, 97 p.

Mann, L.J., 1986, Hydraulic properties of rock units and chemical quality of water for INEL-1-A 10,365-foot deep test hole drilled at the Idaho National Engineering Laboratory, Idaho: U.S. Geological Survey Water-Resources Investigations Report 86-4020 (IDO-22070), 23 p. [Also available at http://pubs.er.usgs.gov/usgspubs/wri/ wri864020.] 
Mann, L.J., and Beasley, T.M., 1994, Iodine-129 in the Snake River Plain aquifer at and near the Idaho National Engineering Laboratory, Idaho, 1990-91: U.S. Geological Survey Water-Resources Investigations Report 94-4053 (DOE/ID-22115), 27 p. [Also available at http://pubs. er.usgs.gov/usgspubs/wri/wri944053.]

McCurdy, D.E., Garbarino, J.R., and Mullin, A.H., 2008, Interpreting and reporting radiological water-quality data: U.S. Geological Survey Techniques and Methods, book 5, chap. B6, 33 p. [Also available at http://pubs.usgs.gov/ $\mathrm{tm} / 05 \mathrm{~b} 06 /$.

Nimmo, J.R., Perkins, K.S., Rose, P.E., Rousseau, J.P., Orr, B.R., Twining, B.V., and Anderson, S.R., 2002, Kilometerscale rapid transport of naphthalene sulfonate tracer in the unsaturated zone at the Idaho National Engineering and Environmental Laboratory: Vadose Zone Journal, v. 1, no. 1, p. 89-101.

Ott, D.S., Cecil, L.D., and Knobel, L.L., 1994, Stable isotopes of hydrogen and oxygen in surface water and ground water at selected sites on or near the Idaho National Engineering Laboratory, Idaho: U.S. Geological Survey Open-File Report 94-55 (DOE/ID-22112), 14 p., http://pubs.er.usgs. gov/usgspubs/ofr/ofr9455.

Paillet, F.L., 2000, Flow logging in difficult boreholesMaking the best of a bad deal, in Proceedings of the 7th international symposium on borehole geophysics for minerals, geotechnical, and groundwater applications, Denver, Colo., 2000: The Minerals and Geotechnical Logging Society, A Chapter at Large of the Society of Professional Well Log Analysts, Houston, Tex., p. 125-135.

Pierce, K.L., and Morgan, L.A., 1992, The track of the Yellowstone hot spot, in Link, P.K., Kuntz, M.A., and Platt, L.B., eds., Regional geology of eastern Idaho and western Wyoming: Geological Society of America Memoir 179, p. 1-53.

Pritt, J.W., 1989, Quality assurance of sample containers and preservatives at the U.S. Geological Survey National Water Quality Laboratory, in Pederson, G.L., and Smith, M.M., comps., U.S. Geological Survey second national symposium on water quality - Abstracts of the technical sessions: U.S. Geological Survey Open-File Report 89-409, 111 p. [Also available at http://pubs.er.usgs.gov/publication/ofr89409.]

Robertson, J.B., Schoen, Robert, and Barraclough, J.T., 1974, The influence of liquid waste disposal on the geochemistry of water at the National Reactor Testing Station, Idaho, 1952-1970: U.S. Geological Survey Open-File Report 73-238 (IDO-22053), $231 \mathrm{p}$.
Rose, D.L., and Schroeder, M.P., 1995, Methods of analysis by the U.S. Geological Survey National Water Quality Laboratory—Determination of volatile organic compounds in water by purge and trap capillary gas chromatography/ mass spectrometry: U.S. Geological Survey Open-File Report 94-708-W, 26 p. [Also available at http://pubs. er.usgs.gov/publication/ofr94708W.]

Self, S., Keszthelyi, L., and Thordarson, T., 1998, The importance of pahoehoe: Annual Review of Earth and Planetary Sciences, v. 26, p. 81-110.

Shervais, J.W., Vetter, S.K., and Hanan, B.B., 2006, Layered mafic sill complex beneath the eastern Snake River PlainEvidence from cyclic geochemical variations in basalt: Geology, v. 34, no. 5, p. 365-368.

Sill, D.S., and Sill, C.W., 1994, Simultaneous determination of the actinides in small environmental samples: Radioactivity and Radiochemistry, v. 5, no. 2, p. 8-19.

Thatcher, L.L., Janzer, V.J., and Edwards, K.W., 1977, Methods for determination of radioactive substances in water and sediments: U.S. Geological Survey Techniques of Water-Resources Investigations, book 5, chap. A5, 95 p. [Also available at http://pubs.usgs.gov/twri/twri5a5/.]

Theis, C.V., 1935, The relation between the lowering of the piezometric surface and the rate and duration of discharge of a well using groundwater storage: Transaction of the American Geophysical Union, v. 16, p. 519-524.

Timme, P.J., 1995, National Water Quality Laboratory, 1995 services catalog: U.S. Geological Survey Open-File Report 95-352, 120 p. [Also available at http://pubs.er.usgs.gov/ publication/ofr95352.]

Toran, Laura, 1982, Isotopes in ground-water investigations: Ground Water, v. 20, no. 6, p. 740-745.

U.S. Department of Energy, 1995, Radiochemistry manual, rev. 10: Idaho Falls, Idaho, U.S. Department of Energy, Radiological and Environmental Sciences Laboratory [variously paged].

U.S. Environmental Protection Agency, 2014, Protection of environment-Code of Federal Regulations 40, part 141: Washington, D.C., Office of Federal Archives and Records Administration [variously paged].

U.S. Geological Survey, 1985, National Water summary 1984-Hydrologic events, selected water-quality trends, and ground-water resources: U.S Geological Survey WaterSupply Paper 2275, 467 p. [Also available at http://pubs. er.usgs.gov/publication/wsp2275.] 
U.S. Geological Survey, 2015, Changes to National Water Quality Laboratory (NWQL) procedures used to establish and verify laboratory detection and reporting limits: National Water Quality Laboratory Technical Memorandum 15.02., accessed January 26, 2016, at http://wwwnwql. cr.usgs.gov/rapi-notes/15-14_NWQL_TM_15-02_ (DQCALC).pdf.

U.S. Geological Survey, variously dated, National field manual for the collection of water-quality data: U.S. Geological Survey Techniques of Water-Resources Investigations, book 9, chaps. A1-A9, [Also available at http://water.usgs. gov/owq/FieldManual/.]

Wershaw, R.L., Fishman, M.J., Grabbe, R.R., and Lowe, L.E., eds., 1987, Methods for the determination of organic substances in water and fluvial sediments: U.S. Geological Survey Techniques of Water-Resources Investigations, book 5, chap. A3, 80 p. [Also available at http://pubs. er.usgs.gov/publication/twri05A3.]
Whitehead, R.L., 1986, Geohydrologic framework of the Snake River Plain, Idaho and eastern Oregon: U.S. Geological Survey Hydrologic Investigations Atlas HA-681, scale 1:1,000,000, 3 sheets.

Whitehead, R.L., 1992, Geohydrologic framework of the Snake River Plain regional aquifer system, Idaho and eastern Oregon: U.S. Geological Survey Professional Paper 1408-B, 32 p. [Also available at http://pubs.er.usgs.gov/ publication/pp1408B.] 


\section{Appendixes}

Appendixes A-C are Adobe ${ }^{\circledR}$ PDF files and are available for download at http://dx.doi.org/10.3133/sir20165088.

\section{Appendix A. Material Safety Data Sheets}

Appendix B. Core Logs for TAN-2271 and TAN-2272

Appendix C. Archive Approval Memo 

Publishing support provided by the U.S. Geological Survey Science Publishing Network, Tacoma Publishing Service Center

For more information concerning the research in this report, contact the Director, Idaho Water Science Center

U.S. Geological Survey

230 Collins Road

Boise, Idaho 83702

http://id.water.usgs.gov 
